\section{The \\ University \\ of Chicago \\ Law Review}

- 1993 by The University of Chicago

\title{
Property Rules and Liability Rules in Unconscionability and Related Doctrines
}

\author{
Richard Craswell $\dagger$
}

\section{Table of Contents}

I. Theory ............................. 3

A. Choosing Between Property and Liability Rules 7

1. Deterring improper consent .......... 7

2. The cost of obtaining proper consent .... 8

3. An analogy to selecting default rules ..... 12

4. Analogies in restitution ............. 14

B. Judging "Reasonableness" Under a Liability Rule ........................ 15

1. Procedural vs. substantive unconscionability 17

2. Possible substantive criteria .......... 20

3. Higher prices vs. more favorable terms .... 29

4. Reliance on pre-existing default rules .... 32

C. Defining "Proper" Consent ............. 34

† Carolyn Craig Professor of Law, University of Southern California Law Center. This paper has been significantly improved by the comments of Scott Altman, Ian Ayres, Lucien Bebchuk, Randy E. Barnett, Robert Cooter, David D. Friedman, Richard S. Gruner, Gregory C. Keating, Leonard J. Long, Edward J. McCaffery, Stephen J. Morse, A. Mitchell Polinsky, Richard A. Posner, Elyn R. Saks, W. David Slawson, Mathew L. Spitzer, Nomi M. Stolzenberg, and participants in workshops at the University of California at Berkeley, Chicago, Georgetown, Harvard, Pennsylvania, Stanford, and USC. The USC Law Center Summer Research Fund provided financial assistance. 
1. Political process values .............. 37

2. Incentives and institutional competence... 38

3. Substantive tests in the definition of

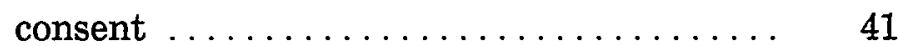

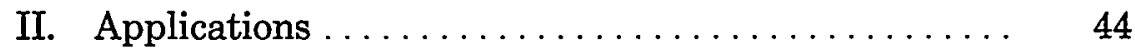

A. Inadequate Alternatives . . . . . . . . . . $\quad 45$

1. Duress and necessity ............... 45

2. Monopoly .................... 46

3. Inability to obtain better terms........ 47

4. Take-it-or-leave-it negotiating postures .... 50

B. Inadequate Information .............. 51

1. Fraud .................... 52

2. Misleading acts or omissions ......... 53

3. Confusing or unreadable contracts ...... 57

C. Inadequate Mental Competence ........... 60

1. Undue influence $\ldots \ldots \ldots \ldots \ldots \ldots \ldots .60$

2. Incapacity .................... 61

Guido Calabresi and Douglas Melamed introduced the distinction between property rules and liability rules just over twenty years ago. ${ }^{1}$ Writing primarily about property and tort law, Calabresi and Melamed pointed out that a complete description of the law in those areas requires not only a specification of the entitlements to be protected, but also a specification of the kind of protection to be provided. A property rule strictly prohibits $\mathrm{X}$ from infringing Y's entitlement, with the prohibition enforced by injunctive relief or, if necessary, by criminal sanctions. A liability rule, in contrast, protects $\mathrm{Y}$ only by allowing him to collect compensatory damages if $\mathrm{X}$ infringes his entitlement. ${ }^{2}$

While Calabresi and Melamed wrote about cases in which $X$ takes from $\mathrm{Y}$ without any pretense of a contract, similar issues arise if $\mathrm{X}$ tries to take from $\mathrm{Y}$ under color of a contract that was not properly formed. If $\mathrm{X}$ forces $\mathrm{Y}$ to sign a contract at gunpoint, for example, or if she uses fraud to trick him into signing, the resulting "contract" will not be recognized as valid. Under the modern doctrine of unconscionability, $\mathrm{Y}$ might also be released from onerous clauses hidden in fine print, or from contracts he

\footnotetext{
1 Guido Calabresi and A. Douglas Melamed, Property Rules, Liability Rules, and Inalienability: One View of the Cathedral, 85 Harv L Rev 1089 (1972).

2 In each of my examples, $\mathrm{X}$ is the alleged wrongdoer and $\mathrm{Y}$ the complaining victim. For convenience in the use of pronouns, all examples involve a female $\mathrm{X}$ and a male $\mathrm{Y}$.
} 
agreed to only because of X's monopoly position. While there has been much controversy concerning whether fine print or monopoly ought to invalidate X's contract, too little attention has been paid to the two forms of protection $\mathrm{Y}$ can be given if X's contract is indeed invalidated. Roughly speaking, if a property rule protects $\mathrm{Y}$, then $\mathrm{X}$ cannot enforce any obligation against him; $\mathrm{X}$ must negotiate in some more acceptable way if she wants to create an enforceable obligation. In contrast, if a liability rule protects $\mathrm{Y}$, then $\mathrm{X}$ can enforce those obligations whose substance seems reasonable to a reviewing court, notwithstanding any improprieties involved in the contract's formation.

Part I of this Article develops the distinction between property rules and liability rules in more detail and discusses how courts should choose between these two forms of protection in cases where $\mathrm{X}$ has not properly obtained Y's consent. It also discusses how courts should make the choice between the better of these alternatives and the remaining possibility: enforcing X's contract as written, without any judicial inquiry into the reasonableness of its terms. The distinction between property rules and liability rules is also used to explain why both "substantive unconscionability" and "procedural unconscionability" are required to invalidate X's contract in certain cases (though not in all), and to evaluate the substantive criteria courts might use in determining the reasonableness of contract terms in any case where only the unreasonable terms are to be invalidated. Part II then applies Part I's analysis to a series of actual contract problems.

\section{Theory}

In property and tort law, liability rules permit $\mathrm{X}$ to infringe $Y$ 's entitlement, but require her to compensate $Y$ with monetary damages. To implement a liability rule, therefore, the court must not only decide whether an infringement has taken place, but must also determine damages. The damage award can be viewed as a judicially-determined "price" that X must pay for her infringement. ${ }^{3}$ A liability rule thus allows $X$ to purchase the use of Y's entitlement without negotiating with $\mathrm{Y}$ directly: $\mathrm{X}$ can simply take the entitlement, then allow the court to select an appropriate price. Property rules, by contrast, are designed to deter $\mathrm{X}$ from taking

\footnotetext{
S Robert Cooter, Prices and Sanctions, 84 Colum L Rev 1523, 1523-25 (1984). A liability rule is one example of what Cooter calls a "price," while a property rule (more precisely, the penalty imposed on one who violates a property rule) is one example of what Cooter calls a "sanction."
} 
Y's entitlement unless $\mathrm{X}$ negotiates with $\mathrm{Y}$ and the two settle on a mutually agreeable price.

In contract law, it has often been recognized that the remedies for breach of contract can be classified as either property rules or liability rules. ${ }^{4}$ The ordinary remedy of expectation damages resembles a liability rule, for it allows one party to break the contract whenever she is willing to pay the court's estimate of the value of her performance to the other party. By contrast, the remedy of specific performance protects the promisee with a property rule, barring the promisor from breaking the contract unless she negotiates her release from the promisee. The same is true of other damage measures designed to deter breach rather than merely to compensate the promisee-for example, in terrorem penalty clauses or punitive damages. ${ }^{5}$

Though it does not appear to have been noted before, the defenses available at the time of contract formation can also be classified as property rules or liability rules. The defense of duress, for example, protects victims with a property rule. If $\mathrm{X}$ puts a gun to Y's head and forces him to sign a contract of sale, X cannot simply take the goods and then, when the duress is pointed out to a court, offer to keep the goods and pay whatever reasonable value the court assigns. Instead, $\mathrm{Y}$ is entitled to rescind the contract and take his goods back. This result forces $\mathrm{X}$ to negotiate properly with $\mathrm{Y}$ in order to acquire Y's goods-with a "proper" negotiation, in this context, meaning negotiation without the use of duress. In this respect, the doctrine of duress protects $\mathrm{Y}$ with the equivalent of a property rule.

Other defenses provide only the protection of a liability rule. Suppose, for example, that $\mathrm{Y}$ is a shipwrecked sailor and $\mathrm{X}$ commands the only vessel in position to rescue him. Suppose further that $\mathrm{X}$ takes advantage of her position to demand that $\mathrm{Y}$ pay an exorbitant price for being rescued. Finally, suppose that the hard choice facing $\mathrm{Y}$-agree to X's terms or drown-is deemed sufficient to invalidate the resulting contract.

This last assumption is somewhat controversial. It can be argued that Y's economic or physical hardship should not be sufficient to release him from the resulting contract, so long as X's

- This analogy was first drawn in Anthony T. Kronman, Specific Performance, $45 \mathrm{U}$ Chi L Rev 351, 352 (1978).

- On the connection between punitive damages and property rules, see David D. Haddock, Fred S. McChesney and Menahem Spiegel, An Ordinary Economic Rationale for Extraordinary Legal Sanctions, 78 Cal L Rev 1 (1990). 
wrongful acts did not cause the hardship. ${ }^{6}$ At this point, however, my concern is with the further distinction a court must make even if it accepts that $\mathrm{Y}$ is not bound by a contract signed under conditions of dire necessity. Specifically, the law must protect $Y$ with either a property rule or a liability rule. A property rule would prevent $\mathrm{X}$ from acquiring any enforceable claim against $\mathrm{Y}$ unless and until she obtains his agreement under "proper" conditions-that is, conditions untainted by economic or physical necessity. By contrast, a liability rule would allow $\mathrm{X}$ to acquire an enforceable claim against $\mathrm{Y}$ even without obtaining his untainted consent, but the amount of the claim would be limited to a reasonable value determined by the courts. Courts actually do the latter in these cases, if they accord $\mathrm{Y}$ any protection at all. In doctrinal terms, the courts treat Y's necessity as a complete defense to any contractual claim $\mathrm{X}$ might raise, but allow $\mathrm{X}$ to sue in restitution for the court-determined reasonable value of her services. ${ }^{7}$ In the terms of Calabresi and Melamed, courts protect $\mathrm{Y}$ with a liability rule rather than a property rule.

It should be noted that, in order to classify the rules of contract formation as property rules or liability rules, I have had to introduce the notion of "proper" or "untainted" consent. By this I mean nothing more than the set of procedures which, if followed, will make an obligation enforceable regardless of whether the content of the obligation seems reasonable to a reviewing court. In analytic jurisprudence, these procedures would be described as contract law's "enabling rules." Calabresi and Melamed required no such concept, for in their analysis the infringer, $\mathrm{X}$, chose between the two extreme strategies of (1) negotiating and obtaining Y's unquestionably proper consent, or (2) invading Y's interests without

\footnotetext{
- See, for example, Richard A. Epstein, Unconscionability: A Critical Reappraisal, $18 \mathrm{~J}$ L \& Econ 293, 297 (1975).

' See, for example, Post $v$ Jones, 60 US (19 How) 150, 159-60 (1856). See generally Grant Gilmore and Charles L. Black, Jr., The Law of Admiralty § 8-15 at 578-79 (Foundation, $2 \mathrm{~d}$ ed 1975).

B H.L.A. Hart, The Concept of Law 18-25 (Clarendon, 1961). There are some contracts-contracts of slavery, for example-that will not be enforced no matter how knowing and voluntary the procedure by which they were formed. These contracts have no enabling rules: in Calabresi and Melamed's terms, Y's entitlement not to be sold into slavery is inalienable. Calabresi and Melamed, 85 Harv L Rev at 1111-15 (cited in note 1). Inalienable entitlements are beyond the scope of this paper (but see note 52). Further discussions of inalienable entitlements can be found in Randy $\mathrm{E}$. Barnett, Contract Remedies and Inalienable Rights, 4 Soc Phil \& Policy 179 (1986); Richard A. Epstein, Why Restrain Alienation?, 85 Colum L Rev 970 (1985); Margaret Jane Radin, Market-Inalienability, 100 Harv L Rev 1849 (1987); Susan Rose-Ackerman, Inalienability and the Theory of Property Rights, 85 Colum L Rev 931 (1985).
} 
negotiating at all. My concern is with a third set of cases in which $\mathrm{X}$ purports to have obtained Y's consent, but may have done so in an improper way. My analysis thus requires a distinction between: (1) cases where $\mathrm{X}$ properly negotiates and obtains Y's consent before asserting rights against $Y$, and (2) cases where $X$ asserts rights against $\mathrm{Y}$ without having properly obtained Y's consent.

Viewed in these terms, the law of contract formation must perform three distinct tasks. First, the law must develop some definition of "proper" consent. Second, in those cases lacking proper consent, courts must decide whether to protect $\mathrm{Y}$ with a property rule or a liability rule. Third, in those cases where $\mathrm{Y}$ is protected with a liability rule, there must be some criteria by which the court can decide what obligation would be most "reasonable." Figure 1 depicts the relationship among these tasks in the form of a standard decision tree.

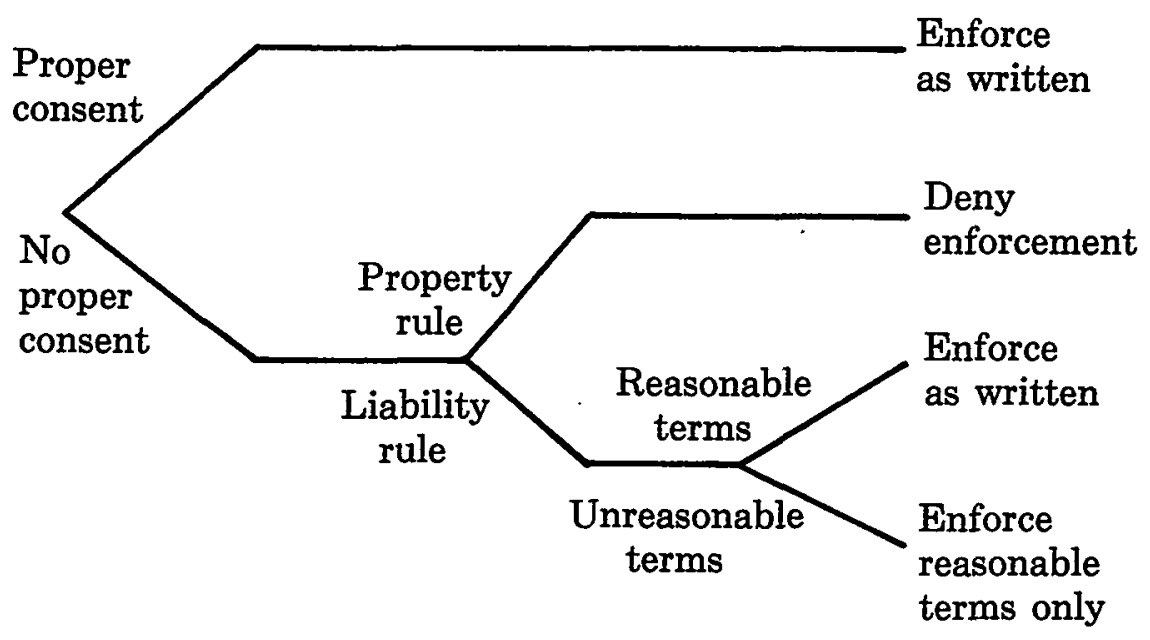

Figure 1

In this Article, I propose to sidestep the first of these tasks for as long as possible by simply accepting arguendo various definitions of proper consent. Moreover, the definitions I accept will usually be the most stringent: the definitions that most often lead to a conclusion that Y's consent was not properly obtained. This allows me to focus on the second and third tasks: the choice between property rules and liability rules in cases which lack proper consent, and the criteria for deciding which obligations should be enforced when proper consent is lacking and liability rules apply. Only then, in the final section of Part I, do I discuss the implica- 
tions this analysis might have for the definition of proper consent. In terms of the decision tree depicted in Figure 1, I propose to begin with the lower branches and work backwards toward the initial definition of consent.

\section{A. Choosing Between Property and Liability Rules}

1. Deterring improper consent.

In property and tort law, property rules are designed to deter $X$ from invading $Y$ 's interests. In contract law, they are designed to deter $\mathrm{X}$ from failing to obtain Y's proper consent. Figure 1 illustrates how adopting a property rule can make the lower branches of the tree sufficiently unattractive to $X$ that she chooses to obtain $Y$ 's proper consent. If $X$ obtains Y's proper consent, the case moves to the upper branch of the decision tree, and X's contract will be enforced according to its terms.

One way to make the lower branches of the tree unattractive to $\mathrm{X}$ is to not enforce any obligation whatsoever on behalf of any $\mathrm{X}$ who has failed to obtain Y's proper consent. For example, if $\mathrm{X}$ forces $Y$ to purchase her goods at gunpoint, the court can allow $Y$ to rescind the contract entirely. This outcome may deter $X$ from using duress because it denies $X$ any profit from her dealings with $\mathrm{Y}$, unless she properly obtains Y's consent.

Some cases, however, may require a stronger penalty to deter $X$ (and others like her) from using duress, or from otherwise failing to obtain Y's proper consent. Under the rule described above, the worst that can happen to $\mathrm{X}$ is that she will have to rescind the contract. If $Y$ would not buy $X$ 's goods without a gun to his head, $\mathrm{X}$ will be no worse off if she tries the gun and fails than if she did not use the gun in the first place. In these cases, to fully deter duress some penalty heavier than mere non-enforcement is needed. For example, $\mathrm{X}$ could be barred from her right to recover any goods delivered to $\mathrm{Y}$ pursuant to the now-invalid contract-although only by coincidence would this additional sanction happen to achieve just the right level of deterrence. Stronger deterrence could also be obtained by subjecting $X$ to punitive damages, criminal penalties, or any other augmented sanction. ${ }^{9}$ There

\footnotetext{
- For a similar suggestion, see Ian Ayres and Robert Gertner, Filling Gaps in Incomplete Contracts: An Economic Theory of Default Rules, 99 Yale L J 87, 126 n 174 (1989).
} 
is a danger though: in some settings stronger sanctions may induce overdeterrence. ${ }^{10}$

In short, it will not always be easy to determine the optimal penalty to use in implementing a property rule. Nevertheless, rescinding the contract and refusing to enforce any of X's terms will rarely be so severe a sanction as to induce overdeterrence, which suggests that rescission at least makes sense as a minimum sanction. Moreover, rescission also has the advantage of administrative convenience, as it does not require the courts to enforce anything on behalf of either party. Thus, in any case where we want to deter $\mathrm{X}$ from entering into a transaction without obtaining Y's proper consent, protecting $\mathrm{Y}$ with a property rule has much to recommend it.

The harder question is whether we always want to deter $\mathrm{X}$ from entering into a transaction without obtaining proper consent. The preceding analysis assumed that the law's goal was to induce the X's of the world to obtain proper consent, but that goal will not always be appropriate. Indeed, the insight of Calabresi and Melamed was that in some instances consent is too costly to obtain, so the law should not attempt to deter all nonconsensual transactions. As the following subsection will demonstrate, a similar point can be made about the cost of obtaining proper consent in contractual settings.

\section{The cost of obtaining proper consent.}

Property rules require $X$ to secure Y's actual consent to any taking, while liability rules rest (at most) on a kind of hypothetical consent, if we presume $\mathrm{Y}$ would have been willing to sell his interest at the court-determined price. Property rules are thus preferable under any autonomy-based theory that attaches particular importance to a right-holder's actual rather than hypothetical consent. ${ }^{11}$ Rules that induce the parties to negotiate to actual con-

10 If the rules defining duress (and other violations of Y's proper consent) are at all uncertain, severe sanctions could produce a "chilling effect" which would cause $\mathrm{X}$ to avoid any conduct that even approaches violating Y's rights. See, for example, Steven Shavell, Economic Analysis of Accident Law 79-83, 93-99 (Harvard, 1987) (analyzing uncertainty in negligence law); Richard Craswell and John E. Calfee, Deterrence and Uncertain Legal Standards, $2 \mathrm{~J}$ L Econ \& Org 279 (1986). If X is risk-averse, higher penalties combined with uncertain enforcement can also impose direct welfare losses by increasing X's risk-bearing costs. Louis Kaplow, The Optimal Probability and Magnitude of Fines for Acts That Definitely Are Undesirable, 12 Intl Rev L \& Econ 3 (1992).

${ }_{11}$ For various perspectives on the relation between actual and hypothetical consent, see Randy E. Barnett, The Sound of Silence: Default Rules and Contractual Consent, 78 Va L 
sent may also have efficiency advantages, for if the court selects a price on behalf of the parties, an unduly low price could permit an inefficient taking while an unduly high price could block an efficient one. As Calabresi and Melamed put it:

[W] hy not convert all property rules into liability rules? . . . Liability rules represent only an approximation of the value of the object to its original owner and willingness to pay such an approximate value is no indication that it is worth more to the thief than to the owner. In other words, quite apart from the expense of arriving collectively at such an objective valuation, it is no guarantee of the economic efficiency of the transfer. ${ }^{12}$

In some tort or nuisance cases, however, it may be unduly expensive to require $\mathrm{X}$ to obtain Y's consent prior to infringing Y's entitlements. If $\mathrm{X}$ is an automobile driver, it would be prohibitively expensive for her to negotiate with each pedestrian to determine a mutually agreeable rate of compensation for any future injuries. If $\mathrm{X}$ owns a factory whose pollution affects an entire urban area, it would be equally prohibitive for her to negotiate a mutually agreeable price with every affected resident. If acquiring the consent of all victims would be unduly expensive, Calabresi and Melamed suggest that liability rules may be more attractive. ${ }^{13}$

Essentially the same analysis can be applied to contract formation cases. As the examples in the following paragraphs illustrate, even where only two parties are involved, the costs of obtaining Y's "proper" consent depend heavily on just what is

Rev 821 (1992); Randy E. Barnett, Rational Bargaining Theory and Contract: Default Rules, Hypothetical Consent, the Duty to Disclose, and Fraud, 15 Harv J L \& Pub Pol 783 (1992); David Charny, Hypothetical Bargains: The Normative Structure of Contract Interpretation, 89 Mich L Rev 1815 (1991); Jules L. Coleman, Douglas D. Heckathorn, and Steven M. Maser, A Bargaining Theory Approach to Default Provisions and Disclosure Rules in Contract Law, 12 Harv J L \& Pub Pol 639 (1989); Richard Craswell, Efficiency and Rational Bargaining in Contractual Settings, 15 Harv J L \& Pub Pol 805 (1992).

12 Calabresi and Melamed, 85 Harv L Rev at 1125 (cited in note 1)(footnote omitted). Depending on the price the court sets for an infringement, liability rules may also produce different distributional effects than property rules, thus giving rise to undesirable strategic incentives. For a discussion of these issues, see Susan Rose-Ackerman, I'd Rather Be Liable Than You: A Note on Property Rules and Liability Rules, 6 Intl Rev L \& Econ 255 (1986); David D. Haddock and Fred S. McChesney, Bargaining Costs, Bargaining Benefits, and Compulsory Nonbargaining Rules, 7 J L Econ \& Org 334 (1991); Haddock, McChesney, and Spiegel, 78 Cal L Rev at 13-18, 35-51 (cited in note 5). These distributional effects are less significant when liability rules are applied to contract formation, because a party who is subject to an unfavorable liability rule may be able to respond by raising her price. See note 48.

1s Calabresi and Melamed, 85 Harv L Rev at 1106-10 (cited in note 1). 
deemed necessary for Y's consent to be proper. ${ }^{14}$ In some cases, therefore, it may be appropriate to spare $\mathrm{X}$ that task by adopting a liability rule.

Consider first a case of duress, in which the only impediment to proper consent is that X held a gun to Y's head while he signed the contract. $\mathrm{X}$ could easily have removed this impediment by removing the gun. Accordingly, this case warrants protecting $\mathrm{Y}$ by means of a property rule, under which $X$ will not be allowed to enforce any obligations against $\mathrm{Y}$ if she secures his agreement at gunpoint.

A different conclusion is required in most cases of physical necessity, as when $\mathrm{Y}$ is a shipwrecked sailor and $\mathrm{X}$ refuses to take him on board unless he promises to pay her an exorbitant sum. Even if we assume that consent given under dire necessity does not qualify as "proper" consent, protecting $\mathrm{Y}$ with a property rule has little to recommend it. A property rule prevents $\mathrm{X}$ from collecting any payment from $\mathrm{Y}$ unless she gets $\mathrm{Y}$ 's agreement under conditions constituting proper consent. But if consent under conditions of dire necessity is deemed not to constitute proper consent, there is no way for X to obtain Y's proper consent to any obligation, because in this case there is no way to eliminate Y's dire necessity. ${ }^{16}$ In short, applying a property rule in this scenario would bar $\mathrm{X}$ from collecting even a reasonable amount for her rescue services. This outcome suggests that if dire necessity is deemed inconsistent with proper consent, $\mathrm{Y}$ ought to be protected by a liability rule rather than a property rule.

Liability rules may also be appropriate in cases involving fineprint contracts. Suppose that X sells $\mathrm{Y}$ an automobile pursuant to a contract with a number of fine-print clauses that limit the scope of her warranty. Suppose, too, that consumers such as $\mathrm{Y}$ are deemed not to be under any duty to read the fine print, so that Y's signature on the contract does not represent proper consent to terms that have not been pointed out and explained to him. (If Y's signature is itself taken as proper consent to everything in the con-

\footnotetext{
14 Two-person negotiations may also be costly if strategic posturing and the threat of hold-outs prevent the parties from agreeing on efficient terms. In two-party negotiations, however, these costs are not normally thought to justify giving one party the equivalent of the power of eminent domain, thereby allowing her to acquire enforceable obligations (at a court-determined price) in spite of the other party's hold-out. Consequently, in this paper I ignore these negotiating costs by assuming them to be zero.

${ }^{15} \mathrm{X}$ could, of course, rescue $\mathrm{Y}$ for free, then begin bargaining with him once he is safe on land-but once $\mathrm{Y}$ is safe on land, he no longer has any need to purchase $\mathrm{X}$ 's rescue services.
} 
tract, then enforcement of the contract will not violate any of Y's entitlements, and the choice between property rules and liability rules will never arise).

This example is not quite like that of the shipwrecked sailor, for in this case $\mathrm{X}$ can remove the impediment to proper consent. For example, in Gerhardt $v$ Continental Insurance Companies, ${ }^{16}$ the buyer sought reimbursement from an insurance company to cover her liability (under New York workers' compensation law) for an injury suffered by her domestic servant. The policy excluded coverage for just this sort of liability, but the buyer had not read the policy and was unaware of this exclusion. The insurer could have prevented this misunderstanding by pointing out the exclusion to the buyer and, if necessary, explaining its practical significance. Thus, protecting the buyer in this case with a property rule could encourage sellers to explain such provisions in the future. Under a property rule, no seller would be allowed to enforce any limitation in a fine-print contract that had not been pointed out and explained prior to the sale.

While sellers can provide such explanations, however, the transaction costs of doing so could be very high. If the failure to point out or explain a clause triggers a property rule, no fine-print clauses-not even substantively reasonable ones-will be enforceable unless they have first been pointed out and explained. But the insurance policy in Gerhardt contained a number of other exclusions in fine print, including clauses excluding coverage of accidents involving sailboats over 26 feet, motorboats of more than fifty horsepower, or "midget automobiles."17 The court described the policy's exclusions as running to "many printed pages" of fine print. ${ }^{18}$ Moreover, many of these exclusions would have been complicated to explain-as the court observed, the buyer "might not know anything at all about the difference between a common law liability claim and a workmen's compensation claim . ..."19 If none of these clauses could be enforced without a full explanation in advance, then no legally enforceable insurance policy could ever be sold except to buyers who were willing to attend a three-day seminar explaining all the possible risks that were or were not covered by the policy.

\footnotetext{
1648 NJ 291, 225 A2d 328 (1966).

$27225 \mathrm{~A} 2 \mathrm{~d}$ at 330 .

18 Id at 329.

10 Id at 333 .
} 
To be sure, if society placed a high enough value on consumer education, three-day seminars prior to every sale might be seen as enhancing the quality of life, in which case a property rule designed to induce such seminars would make perfect sense. The decision about which transaction costs are worth incurring thus depends partly on the values served by those costs, as well as on their magnitude. My only point here is that if one prefers to leave consumers more time to pursue goals other than attending three-day seminars, the problem posed by consumers' unawareness of fineprint terms would be better addressed by a liability rule rather than a property rule. A liability rule would allow sellers to enforce reasonable fine-print exclusions even if they had not been pointed out in advance of the sale, thus eliminating the need for three-day seminars. $^{20}$

In short, a liability rule reduces transaction costs by freeing sellers from having to negotiate for "proper" consent, so long as the sellers are willing to enforce only those terms the court considers reasonable. If the transaction costs saved by this method are large enough, it may be better to relieve sellers of the burden of obtaining proper consent by protecting buyers with a liability rule rather than a property rule. However, the desirability of this approach (as well as its success) will depend heavily on how a court decides what obligations are sufficiently "reasonable" to enforce once a liability rule is applied. This topic will be addressed in Section I.B.

\section{An analogy to selecting default rules.}

Before turning to Section I.B, it should be noted that the analysis just presented has much in common with that recently applied by Ian Ayres and Robert Gertner to the selection of default rules. ${ }^{21}$ Default rules apply when parties to an otherwise enforceable contract fail to provide for some particular contingency. Examples include the doctrines of impracticability and mistake, which allocate the risks of unexpected problems if those risks were not expressly allocated in the contract; and the various implied warranty doctrines, which allocate the risks of product failure for a contract that does not expressly specify the extent of the seller's warranty.

20 Another solution, essentially equivalent to that described in the text, is to treat buyers as having in fact consented to all reasonable terms contained in the fine-print contract, but not as having consented to any unreasonable terms. This solution is discussed in the text accompanying notes 79-81.

${ }^{21}$ Ayres and Gertner, 99 Yale L J 87 (cited in note 9). 
It has often been suggested that default rules should reflect whatever risk-allocation most contracting parties would choose, if only to save most parties the cost of transacting around the default rule. ${ }^{22}$ Ayres and Gertner point out, however, that the law often adopts what they call a "penalty default rule"- that is, a rule chosen deliberately to be unattractive to at least one of the contracting parties. For example, if the parties to a sales contract fail to specify the quantity they intend to buy or sell, the court will not fill this gap with its estimate of a reasonable quantity. Instead, the court will simply refuse to enforce the contract: it will set a default quantity of zero. Such a rule gives the parties an incentive to spell out the quantity in the contract, and frees the court from having to construct its own estimate of a "reasonable" quantity. ${ }^{23}$

A penalty default rule thus serves many of the same functions as a property rule. Each encourages the parties to work out their own solution through explicit negotiations, freeing the courts from having to decide what solution would be most reasonable. By contrast, the alternative to a penalty default rule-a default allocation chosen for its inherent reasonableness, or what Ayres and Gertner called a "majoritarian" default rule ${ }^{24}$-is very similar to a liability

${ }^{22}$ For discussions of this principle see id at 93-95; Richard Craswell, Contract Remedies, Renegotiation, and the Theory of Efficient Breach, $61 \mathrm{~S}$ Cal L Rev 629, 633 (1988); Charles J. Goetz and Robert E. Scott, The Limits of Expanded Choice: An Analysis of the Interactions Between Express and Implied Contract Terms, 73 Cal L Rev 261 (1985); Richard A. Posner and Andrew M. Rosenfield, Impossibility and Related Doctrines in Contract Law: An Economic Analysis, 6 J Legal Stud 83, 88-89 (1977); Alan Schwartz, Proposals for Products Liability Reform: A Theoretical Synthesis, 97 Yale L J 353, 361 (1988).

${ }^{23}$ Ayres and Gertner, 99 Yale L J at 95-97 (cited in note 9). As Ayres and Gertner recognized, penalty default rules have much in common with the legal rules Lon Fuller had earlier described as "formalities." Id at 123-25; Lon L. Fuller, Consideration and Form, 41 Colum L Rev 799, 799-806 (1941). For a similar analysis of formalities, see Duncan Kennedy, Form and Substance in Private Law Adjudication, 89 Harv L Rev 1685, 1690-94, 1697-1701 (1976).

24 Ayres and Gertner, 99 Yale $\mathrm{L} J$ at 93 (cited in note 9). Because Ayres and Gertner identify "majoritarian" default rules as those embodying the solution that would be the most reasonable for a majority of contracting pairs, they occasionally attach the label "penalty default rule" to a default rule selected on any other basis, including a default rule that would be most reasonable for some minority of contracting pairs. See id at 108-17 (considering the choice between two possible default rules to govern the allocation of unusually high losses in cases such as Hadley $v$ Baxendale, 9 Ex 341, 156 Eng Rep 145 (1854) (miller sought consequential damages for lost profits when carrier delayed transportation of broken crank shaft)). In Calabresi and Melamed's terminology, each of these default rules is similar to a liability rule, as each requires a court to determine what solution would be most reasonable for at least one group of contracting pairs. The default rules that most resemble property rules are those that embody some arbitrary solution chosen without regard to reasonableness for any contracting pairs. The "zero quantity default," which sets the enforceable quantity at zero for those pairs who fail to specify a quantity, is a good example of a true property rule. 
rule. Under a majoritarian default rule, the parties are free to create an enforceable contract without having explicitly consented to any rule that would govern the issue in question. However, if a dispute arises, the court will select its own (or the legislature's) resolution of that issue, in order to ensure that the only obligations imposed without the parties' explicit consent are those the court (or legislature) deems reasonable.

Given this similarity between penalty default rules and property rules, and between majoritarian default rules and liability rules, it is hardly surprising that the conditions under which majoritarian default rules are preferable are similar to the conditions under which liability rules are preferable. In particular, majoritarian default rules (like liability rules) become more attractive the greater the transaction costs required to explicitly negotiate any given point. Penalty default rules become more attractive when the cost of explicit negotiations is relatively low, and/or when courts are ill-equipped to determine a reasonable solution. ${ }^{25}$ This was exactly the trade-off recommended by Calabresi and $\mathrm{Me}$ lamed; ${ }^{26}$ it is also the trade-off recommended here.

\section{Analogies in restitution.}

In a slightly different guise, the same trade-off is central to the economic analysis of restitution and quasi-contract. Consider, for example, a doctor who encounters an unconscious patient on the street, provides medical services, then submits her bill when the patient recovers. If the patient is unconscious, the cost of securing the patient's explicit consent to pay for the medical services is almost surely prohibitive. Accordingly, Richard Posner has argued that the doctor should be allowed to collect something for her services. ${ }^{27}$ However, Posner would protect unconscious patients by having the court set the amount of the doctor's recovery. This is precisely the protection provided by a liability rule.

By contrast, Posner recommends a different result for the violinist who, without having been asked, plays a lovely serenade just outside someone's window. Posner argues that even if the listener enjoys the serenade, the courts should not let the violinist sue for a reasonable fee for her services, because the violinist (unlike the doctor) could easily have approached the listener beforehand and

\footnotetext{
25 Ayres and Gertner, 99 Yale $L J$ at 96 (cited in note 9 ).

${ }^{26}$ Calabresi and Melamed, 85 Harv $L$ Rev at 1106-10 (cited in note 1).

22 Richard A. Posner, Economic Analysis of Law 134-34 (Little Brown, 4th ed 1992).
} 
explicitly negotiated an acceptable price. The violinist's failure to secure the listener's proper consent should therefore bar her from any recovery whatsoever. ${ }^{28}$ In other words, Posner would protect the listener with a property rule.

In summary, there are many similarities between the following three situations:

(1) cases where one party does not even purport to obtain the other's consent, as in the tort and nuisance cases analyzed by Calabresi and Melamed, or the doctor and the violinist analyzed by Posner;

(2) cases where the parties consent to a contract but do not purport to specify all of the ancillary obligations, as in the default rules analyzed by Ayres and Gertner; and

(3) cases where one party purports to have obtained the other's consent to some specified obligation, but does so by an arguably improper method, as in the unconscionability cases analyzed here.

In each case, the courts can respond by following either of two strategies. One strategy is to decide for the parties which obligations would have been most reasonable: this is the strategy of liability rules or majoritarian default rules. Alternatively, the courts can attempt to induce the parties to decide for themselves what obligations are reasonable: this is the strategy of property rules or penalty defaults. The attractiveness of this second strategy will depend heavily on the costs the parties must incur to create a legally valid agreement. These costs, in turn, are heavily dependent on the rules defining the requirements for "proper" consent. By contrast, the attractiveness of the first strategy-empowering the courts to select reasonable terms for the parties-depends on the difficulties courts face in selecting reasonable terms. In terms of the decision tree depicted in Figure 1, the attractiveness of the path labelled "liability rules" depends in part on the difficulty of the choices courts must make further down that path. These difficulties are addressed in the following section.

B. Judging "Reasonableness" Under a Liability Rule

The hallmark of a liability rule is that it requires the court to distinguish reasonable from unreasonable obligations. Of course,

38 Id at 134. Saul Levmore has labelled this the "market encouraging" effect of denying restitution. Saul Levmore, Explaining Restitution, 71 Va L Rev 65, 79-81 (1985). 
the court need not use the word "reasonableness" to make this decision, but whatever word is used, the court must have some method of deciding which obligations will be enforced when proper consent is lacking. Moreover, because this test comes into play only when proper consent is lacking, the test cannot choose between enforceability and unenforceability based on whether the parties properly consented to the term in question. Instead, the test must distinguish enforceable from unenforceable obligations on the basis of the obligation's content or substance. In this paper, I use "reasonableness" (or "substantive reasonableness") as a catch-all to describe any test that serves this function.

There are several ways in which a reasonableness criterion can be coupled with a liability rule. In the simplest version, the court enforces X's contract as written whenever X obtained Y's proper consent, and the court enforces whatever obligations the court deems reasonable whenever $\mathrm{X}$ failed to obtain Y's proper consent. In this case, any of X's terms whose substance was deemed unreasonable by the court would be struck down, but replaced by obligations the court considers reasonable. ${ }^{29}$

A subtle variation of this approach would prohibit $\mathrm{X}$ from enforcing reasonable terms in place of terms found unreasonable by the court, while allowing $X$ to enforce terms the court considers reasonable. Under this approach, if $\mathrm{X}$ asked only a reasonable price for rescuing $Y$ then she may collect that price, but if she forced $\mathrm{Y}$ to sign a contract containing an exorbitant price then she may not collect anything. This variation provides additional deterrence-not against entering into a contract without obtaining Y's proper consent, as under a property rule, ${ }^{30}$ but against including unreasonable (and unenforceable) terms in contracts where Y's proper consent will not be obtained. Under the rule described in the preceding paragraph, the only "penalty" $\mathrm{X}$ suffers for including an unreasonable term in her contract is that she will only be able to enforce a reasonable term, which leaves her no worse off than if she had used a reasonable term in the first place. This may not sufficiently deter $\mathrm{X}$ from trying to get away with unreasonable

${ }^{29}$ It is also possible for courts to adopt a range of "reasonableness," upholding any of $X$ 's terms that fall within that range, but striking down any terms that fall outside it (and replacing those terms with terms selected from within the range). For a formal model with these attributes, see Avery Katz, Your Terms or Mine? The Duty to Read the Fine Print in Contracts, 21 RAND J Econ 518 (1990).

${ }^{\text {so }}$ See Section I.A.1. 
terms, especially if many buyers do not know their legal rights or do not find it worth their while to take $X$ to court.

In its use of penalties designed to achieve deterrence, the rule just described may seem to have more in common with property rules than liability rules. For most purposes, though, the rule just described is more usefully classified as a liability rule. The rule just described is designed to induce $\mathrm{X}$ to include only reasonable terms in the contract when she has not obtained Y's proper consent. It is not designed to induce her to obtain Y's proper consent, as would be the case under a property rule. Moreover, a property rule achieves its goal by imposing some penalty in every case where $\mathrm{X}$ fails to obtain Y's proper consent, while the rule just described imposes a penalty only when X fails to obtain Y's proper consent and the substance of $X$ 's contract terms is deemed unreasonable by a reviewing court. Thus, in both its purpose and in its requirement of some standard of substantive reasonableness, this rule is best analyzed as a liability rule.

1. Procedural vs. substantive unconscionability.

The fact that liability rules require courts to evaluate the substantive reasonableness of the challenged terms helps explain the relationship between "procedural unconscionability" and "substantive unconscionability." Those two concepts were introduced by Arthur Leff to distinguish between "bargaining naughtiness" (procedural unconscionability) and "evils in the resulting contract" (substantive unconscionability). ${ }^{31}$ Most statements of the law of unconscionability now hold that both procedural and substantive unconscionability are required before courts will grant relief from a challenged term. ${ }^{32}$ Judicial decisions have not consistently followed this principle, however, and some courts have suggested a vaguely mathematical metaphor in which a large amount of one type of unconscionability can make up for only a small amount of the

s1 Arthur Allen Leff, Unconscionability and the Code-The Emperor's New Clause, $115 \mathrm{U} \mathrm{Pa}$ L Rev 485, 487 (1967).

32 See Williams v Walker-Thomas Furniture Co., 350 F2d 445, 449 (DC Cir 1965) (defining an unconscionable contract as one that combines "an absence of meaningful choice on the part of one of the parties [procedural unconscionability] together with contract terms which are unreasonably favorable to the other party [substantive unconscionability]"). 
other. $^{33}$ Some scholars have questioned the utility of the entire distinction. ${ }^{34}$

On the view taken here, the relationship between procedural and substantive unconscionability turns on whether a property rule or a liability rule is the more appropriate method of protecting the weaker party. Under a property rule, procedural unconscionability (or what I call a "lack of proper consent") suffices to invalidate challenged terms, without requiring any showing of substantive unconscionability. For example, if a property rule governs cases of duress, and $\mathrm{X}$ forces $\mathrm{Y}$ to sign a contract at gunpoint, $\mathrm{Y}$ should be excused from the resulting contract without any further showing. That is, $\mathrm{X}$ should not be allowed to reinstate the contract by showing that the price and other terms of the deal were entirely reasonable. Nor should the court enforce other, more reasonable terms in place of those struck down. One point of a property rule, after all, is to spare the court the need to decide which obligations are substantively reasonable, by encouraging the parties to decide such matters themselves.

On the other hand, in cases governed by a liability rule, both procedural unconscionability and substantive unconscionability are prerequisites to relief. If a liability rule applies to fine-print exclusions, and $\mathrm{Y}$ purchases an insurance policy with thirty pages of fine-print exclusions, the mere fact that those exclusions were too many to read or understand should not make each of the exclusions unenforceable. If fine-print problems are properly governed by a liability rule, it must be because we do not seriously want to induce $\mathrm{X}$ to explain every exclusion. A rule that denies enforcement to every unexplained exclusion would therefore be counterproductive, if $\mathrm{X}$ responded by trying to explain every exclusion orally.

Of course, rather than trying to explain every exclusion orally, $\mathrm{X}$ might respond by resigning herself to the fact that the unexplained exclusions would not be enforced. But this result will also be counterproductive if the unexplained exclusions include "reasonable" exclusions that would benefit buyers as well as sellers-for example, exclusions that hold down the costs of insurance

${ }^{33}$ See, for example, Tacoma Boatbuilding Co., Inc. v Delta Fishing Co., Inc., 28 UCC 26, 37 n 20 (W D Wash 1980). See generally James J. White and Robert S. Summers, Uniform Commercial Code § 4-7 (West, 3d ed 1988).

34 Melvin Aron Eisenberg, The Bargain Principle and Its Limits, 95 Harv L Rev 741, 752-54 (1982); Robert A. Hillman, Debunking Some Myths About Unconscionability: A New Framework for U.C.C. Section 2-302, 67 Cornell L Rev 1, 2-5 (1981). 
without significantly increasing most buyers' risks. If a liability rule is indeed appropriate, therefore-in this example, if there are too many reasonable exclusions to be practicably explained-the courts should not respond to a failure to obtain proper consent by refusing to enforce any unexplained obligation. Instead, courts should refuse to enforce only those unexplained obligations that also fail to pass some reasonableness test. In other words, courts should require a showing of both procedural and substantive unconscionability. ${ }^{36}$

This analysis also suggests just how and when greater degrees of procedural unconscionability can substitute for substantive unconscionability. If we worsen the insurance contract example by adding any other factor that would normally trigger (at most) a liability rule-for example, if we add that $Y$ is in desperate need of insurance and cannot survive in business without it - this fact should not have any effect on the required showing of substantive unconscionability. But if we worsen the example by having $\mathrm{X}$ force $\mathrm{Y}$ to purchase the policy at gunpoint, $\mathrm{Y}$ should be released without having to show that any element of the policy was substantively unreasonable. That is, this form of augmented procedural unconscionability should eliminate any requirement that substantive unconscionability be shown as well.

The difference between these examples is not merely that duress is a "worse" form of procedural unconscionability than taking advantage of necessity or failing to explain a fine-print contract, or that duress represents a larger "amount" of procedural unconscionability than either of the other two problems. Both of these figures of speech may perhaps be valid, but they represent at best an awkward groping toward understanding why $\mathrm{Y}$ should have to show substantive unconscionability in one case and not in the other. A better understanding comes from realizing that classic gun-to-the-head duress is a problem which can easily be eliminated by $\mathrm{X}$, while necessity and fine-print terms are problems which $\mathrm{X}$

\footnotetext{
ss There is potential for terminological confusion here, for "substantive unconscionability" is sometimes used to designate clauses whose substance is so bad that they cannot be enforced no matter how fairly and voluntarily $\mathrm{Y}$ agreed to them. This terminology corresponds to what Calabresi and Melamed call an inalienable entitlement. See note 8. When I speak of "substantive unconscionability," I mean nothing more than that the clause fails the criteria of reasonableness used to implement a liability rule. As long as these criteria are applied only to clauses to which $Y$ never properly consented-that is, as long as they are applied only when there is also some form of "procedural unconscionability"-these criteria can be somewhat weaker than the criteria needed to invalidate a term when each party has given his or her proper consent.
} 
either cannot eliminate or cannot eliminate at an acceptable cost. This means that duress is best governed by a property rule, while necessity and failure to explain a fine-print contracts are best governed by a liability rule. To say that substantive unconscionability must be shown in the latter case but not in the former, is simply to restate the point that liability rules require the courts to conduct a substantive analysis of the contested obligation, while property rules impose no such requirement.

\section{Possible substantive criteria.}

How, then, should courts evaluate the substance of a contested obligation when required to do so under a liability rule? When the contested obligation concerns the price $\mathrm{X}$ tries to charge, a court implementing a liability rule will need criteria for deciding what constitutes a reasonable price. For example, in the shipwrecked sailor example, the court will have to determine a reasonable price for Y's rescue services. Applying a liability rule to prices requires the court to operate as a kind of price-setting commission, much like the state commissions formed to regulate public utilities and other natural monopolies. ${ }^{36}$

In most cases, though, the contested obligation concerns a non-price term such as an insurance exclusion or a limitation on the seller's warranty. Indeed, White and Summers report that the number of unconscionability cases challenging an excessive price has "dwindled to a trickle." ${ }^{37}$ Unfortunately, the substantive criteria that might be used to evaluate non-price obligations are more diverse, and cannot easily be reduced to a formula such as "cost

se As the possible critéria for judging the reasonableness of prices have been thoroughly canvassed in the literature on utility regulation, that discussion will not be repeated here. See generally Stephen G. Breyer, Regulation and Its Reform chs 2-3, 8 (Harvard, 1982); Richard Schmalensee, The Control of Natural Monopolies (Heath-Lexington, 1979). For an interesting review of the various criteria reflected in the Aristotelian, Roman, and medieval theories of the "just price" doctrine, see James Gordley, Equality in Exchange, 69 Cal L Rev 1587 (1981).

Of course, as many writers have noted, the record of public utility commissions is not one that inspires confidence. See, for example, Paul L. Joskow and Roger C. Noll, Regulation in Theory and Practice: An Overview, in Gary Fromm, ed, Studies in Public Regulation 1, 49-53 (MIT, 1981); George J. Stigler, The Citizen and the State: Essays on Regulation ch 5 (Chicago, 1975). The fact that public utility commissions have not performed well in trying to set reasonable rates raises questions about how well common law courts can be expected to perform an analogous function. This and other questions concerning the extent of judicial expertise will be taken up in Section I.C.1.

s2 White and Summers, Uniform Commercial Code \$ 4-5 at 194 (cited in note 33). 
plus reasonable profit." This section briefly surveys some of the criteria that might be employed.

a) Economic efficiency. Standard economic analysis compares the amount buyers gain from more favorable obligations, measured by the maximum buyers would be willing to pay for those obligations, to the amount sellers would lose. If the buyer's gain exceeds the seller's losses, the obligation in question will be considered reasonable, and the seller will be allowed to enforce it. If not, the obligation will be considered unreasonable, and enforcement will be barred.

This form of economic analysis has often been criticized for its normative premises, some of which will be discussed below. Even if one accepts its normative premises, however, this form of economic analysis can also be criticized for its difficulty. The relationship between an obligation's net costs and benefits will depend on (1) each party's ability to take precautions to prevent certain losses, (2) each party's knowledge about the relevant risks and precautions, (3) each party's ability to acquire further knowledge, (4) each party's degree of risk-aversion, (5) each party's access to insurance, and (6) the transaction costs involved in enforcing each of the possible obligations-to list just a few of the relevant factors. Often, some of these factors will point in favor of enforcing relatively stringent obligations, while others will argue in the opposite direction.

Indeed, these factors are often analyzed in the economic literature on optimal default rules. As noted earlier, the selection of default rules for parties whose contract is silent has much in common with the task of selecting reasonable obligations for parties who have not properly consented. ${ }^{38}$ Thus, economists have attempted to identify the most efficient remedy for nonperformance, ${ }^{39}$ or the most efficient limits on a seller's responsibility for unexpected diffi-

38 See Section I.A.3.

38 For non-technical introductions to this literature, see Robert Cooter and Thomas Ulen, Law and Economics 288-316 (Harper Collins, 1988); A. Mitchell Polinsky, An Introduction to Law and Economics chs 5, 8 (Little, Brown, 2d ed 1989); Lewis A. Kornhauser, An Introduction to the Economic Analysis of Contract Remedies, $57 \mathrm{U}$ Colo L Rev 683 (1986); Craswell, 61 S Cal L Rev 629 (cited in note 22). 
culties, ${ }^{40}$ or the most efficient allocation of liability in products liability cases. ${ }^{41}$ Unfortunately, this literature is often inconclusive. As Duncan Kennedy once remarked, "It all depends on empirical data that no one ever seems to have ready to hand." 42

To be sure, in many cases the economic analysis may be easy. A warranty that lasts for only thirty seconds is surely inefficient; a rule prohibiting customers from recovering for damage they deliberately inflict on their own automobiles is surely efficient. Where the issues are as simple as these, an efficiency criterion may be applied with a high level of confidence. In other cases, the application of an efficiency criterion is harder-but in these cases, most of the alternatives to an efficiency criterion are equally difficult to apply. Moreover, the alternatives generate other problems of their own, as the remaining portions of this section will illustrate.

b) Alternative cost-benefit tests. The efficiency criterion is often criticized on normative grounds because it measures buyers' benefits by their willingness to pay. This is problematic because a buyer's willingness to pay depends in part on how much money a buyer has, how much he knows about the importance of the term in question, and what he has been socialized to value. ${ }^{43}$ For example, if a buyer incorrectly believes that a product's failure rate is low, and is therefore unwilling to pay very much for extended warranty protection, few would say that extended warranty protection would not benefit this buyer. It seems equally odd to say that a poor buyer, who cannot afford to pay very much for an extended warranty, would therefore receive only a small benefit if he were given one.

This objection suggests an alternative criterion under which benefits would be evaluated by buyers' willingness to pay under

40 See, for example, Posner and Rosenfield, $6 \mathrm{~J}$ Legal Stud 83 (cited in note 22). Recent contributions to this literature include Michelle J. White, Contract Breach and Contract Discharge Due to Impossibility: A Unified Theory, $17 \mathrm{~J}$ Legal Stud 353 (1988); Alan 0. Sykes, The Doctrine of Commercial Impracticability in a Second-Best World, $19 \mathrm{~J}$ Legal Stud 43 (1990); Alan Schwartz, Relational Contracts in the Courts: An Analysis of Incomplete Agreements and Judicial Strategies, 21 J Legal Stud 271 (1992).

${ }^{11}$ For a recent, non-technical survey of this literature, see Schwartz, 97 Yale L J 353 (cited in note 22).

12 Duncan Kennedy, Distributive and Paternalist Motives in Contract and Tort Law, With Special Reference to Compulsory Terms and Unequal Bargaining Power, $41 \mathrm{Md} \mathrm{L}$ Rev 563, 603 (1982).

43 For examples of these criticisms, see Mark Kelman, A Guide to Critical Legal Studies 141-50 (Harvard, 1987); C. Edwin Baker, Starting Points in Economic Analysis of Law, 8 Hofstra L Rev 939 (1980); Duncan Kennedy, Cost-Benefit Analysis of Entitlement Problems: A Critique, 33 Stan L Rev 387 (1981). 
more ideal circumstances, rather than by their actual willingness to pay. For example, we could ask how much a buyer would have paid for an extended warranty if he had known the correct odds of product failure, or how much the buyer would have paid for an extended warranty if he were not so poor. Indeed, welfare economists routinely make the first sort of correction, and evaluate benefits from the standpoint of a fully informed buyer. While it is less conventional to evaluate benefits from the standpoint of buyers who have more money, or who have been differently socialized, there is no reason in principle why these corrections could not be made. ${ }^{44}$ Notice that such corrections strengthen the case for applying a liability rule rather than leaving the selection of terms to X's market incentives, ${ }^{45}$ for alternative criteria such as these entail a larger set of "market failures." As even competitive markets respond only to the demand expressed by consumers' actual willingness to pay, market incentives may frequently lead $\mathrm{X}$ to choose terms which are less than ideal from the standpoint of these alternative criteria.

Using these alternative substantive criteria under a liability rule creates two additional problems, however. First, these criteria will generally be at least as hard to apply as the traditional efficiency test based on actual willingness to pay. Under the alternative criteria considered here, the court must answer all the same questions as under the traditional economic approach, but it must answer them from the standpoint of a hypothetical or idealized buyer, not from the standpoint of actual buyers. Even hypothetical buyers usually care about how much better terms would cost. Thus, a court applying this test must still worry about the effect of more favorable terms on each side's ability to take precautions, on each side's ability to get insurance, and so on. This does little to ease the administrative difficulties associated with a more traditional efficiency test.

The second problem stems directly from this use of hypothetical buyers as the normative benchmark. To see the problem, suppose that richer or better-informed buyers would indeed consider a longer warranty to be worth more than its cost. If nothing is done

\footnotetext{
4 A closely related issue-the extent to which "hypothetical consent" theories should idealize the parties whose hypothetical consent is being considered-is discussed in Charny, 89 Mich L Rev at 1820-21 (cited in note 11). See also Jules L. Coleman, Risks and Wrongs ch 8 (Cambridge, 1992).

18 The choice between protecting $\mathrm{Y}$ with a liability rule and simply enforcing the contract as written (thus leaving the selection of terms to X's market incentives) is discussed in Section I.C.
} 
to cure actual buyers' poverty or lack of information, they will continue to act according to their actual preferences, not the preferences they would have if they were richer or better informed. As a result, at least some of these buyers may refuse to buy the product at all once the longer warranty has been added and the product's price has risen. In short, while the market may not perform very well relative to these alternative cost-benefit criteria, courts that do not have power to regulate sellers' prices are not likely to perform very well either. ${ }^{46}$

To be sure, the possibility that some buyers might be priced out of the market is not necessarily bad, if buyers would be better off not buying the product in question. For example, if the product is an extremely risky one that would not be purchased by perfectly-informed buyers, and if a longer warranty would force the seller to increase the product's price to reflect those risks, the resulting reduction in sales might be defended on efficiency grounds once we adopt the values of a fully-informed buyer. This is the familiar "level of activity" effect analyzed by Steven Shavell. ${ }^{47}$ For many products, however-and especially for those products deemed "necessities"-it is surely the case that buyers would be better off purchasing the product than not purchasing at all. For these products, the possibility that some buyers might be priced out of the market must be taken into account.

It could of course be argued that the full amount of sellers' costs are not always passed on to buyers through higher prices. ${ }^{48}$ If the price increase is less than the sellers' costs, however, then some

6 The problem discussed in this paragraph is thus an example of a "second best" problem, which would disappear only if the underlying problem (poverty or lack of information) could be addressed directly. For a technical analysis of similar second-best problems, see Samuel A. Rea, Jr., Workmen's Compensation and Occupational Safety Under Imperfect Information, $71 \mathrm{Am}$ Econ Rev 80 (1981). For a less technical discussion, see Richard Craswell, Passing On the Costs of Legal Rules: Efficiency and Distribution in Buyer-Seller Relationships, 43 Stan L Rev 361, 391-98 (1991).

4 Steven Shavell, Strict Liability versus Negligence, 9 J Legal Stud 1 (1980).

4 See, for example, Bruce Ackerman, Regulating Slum Housing Markets on Behalf of the Poor: Of Housing Codes, Housing Subsidies and Income Redistribution Policy, 80 Yale L J 1093 (1971). The Ackerman article, and its suggestion that sellers' costs might not always be passed on, produced a flurry of academic responses. Responses focusing particularly on the housing industry include Neil K. Komesar, Return to Slumville: A Critique of the Ackerman Analysis of Housing Code Enforcement and the Poor, 82 Yale L'J 1175 (1973); Bruce Ackerman, More on Slum Housing and Redistribution Policy: A Reply to Professor Komesar, 82 Yale L J 1194 (1973); Werner Z. Hirsch, Joel G. Hirsch, and Stephen Margolis, Regression Analysis of the Effects of Habitability Laws Upon Rent: An Empirical Observation on the Ackerman-Komesar Debate, 63 Cal L Rev 1098 (1975). More general theoretical discussions include Craswell, 43 Stan L Rev 361 (cited in note 46); Kennedy, 41 Md L Rev at 598, 604-14 (cited in note 42); Richard S. Markovits, The Distributive Impact, Allocative 
buyers must be unwilling or unable to pay the full amount of sellers' costs. Under extreme configurations of supply and demand, sellers' prices might not rise any more than the value placed on the more favorable terms by the lowest-valuing buyer, thereby assuring that all other buyers will either gain or (at worst) break even from obtaining the more favorable terms at a higher price. ${ }^{49}$ More commonly, though, the gain to those buyers who would have paid more than the actual price increase for the more favorable terms comes at the expense of those buyers who did not value the favorable terms as much, or who simply could not afford to pay a higher price for them. In that case, the benefit to buyers who get the favorable terms at a relatively low price will have to be balanced against not just the cost to sellers, but also against (a) the cost to buyers who still buy the product but who would rather give up the more favorable terms and pay a lower price, and (b) the cost to buyers who are priced out of the market by the price increase. Moreover, the buyers who are priced out of the market will often be those who are the poorest, least well-informed, or most heavily socialized to place little value on the contract term in question. If so, the costs of the favorable terms will fall most heavily on the very groups this alternative criterion is intended to protect. ${ }^{50}$

c) Pure paternalism. Similar problems arise if we abandon the effort to measure the value of contract terms by the preferences of buyers-either actual buyers, or hypothetical buyers in some more ideal world - and instead evaluate obligations according to some wholly external standard. For example, certain contractual

Efficiency, and Overall Desirability of Ideal Housing Codes: Some Theoretical Clarifications, 89 Harv L Rev 1815 (1976).

to All buyers will gain or break even from inefficient terms only if (1) the supply of the product is absolutely fixed, so that sellers do not reduce the quantity offered for sale; and (2) buyers' willingness to pay for the underlying product correlates exactly with their willingness to pay for the inefficient term, so that those buyers willing to pay the least for the extra term are also those willing to pay the least for the product itself. For discussions of these conditions see, for example, Ackerman, 80 Yale L J at 1102-08 (cited in note 48); Craswell, 43 Stan L Rev at 380-83 (cited in note 46).

so See Craswell, 43 Stan L Rev at 372-85 (cited in note 46). Note, too, that sellers' ability to charge a higher price under a liability rule removes one objection that is often raised against liability rules in the context of property or nuisance law. In property or nuisance law, $\mathrm{X}$ generally does not have any contractual dealings with $\mathrm{Y}$ and, therefore, does not have the opportunity to charge a higher price to make up for her liability. This means that the amount of damages awarded under a liability rule will determine the distribution of wealth between $\mathrm{X}$ and $\mathrm{Y}$, which may create incentives for strategic behavior prior to the actual taking. See note 12 . In contractual relationships, by contrast, $X$ 's ability to raise or lower her price will tend to neutralize the distributional effects of a liability rule. 
rights might be viewed as pure "merit goods," or rights that all buyers ought to have regardless of whether any buyer considers them to be worth their cost. Most merit-good arguments lead to the conclusion that the rights in question should be inalienable, even by properly-consenting parties. A slightly more moderate approach would allow the rights in question to be waived by parties who properly consent to the waiver, but would require that parties whose proper consent could not practicably be obtained be treated as though they had not waived those rights. In other words, a merit-good argument could supply the substantive standard for evaluating contested obligations wherever a liability rule is appropriate, without overriding cases of actual consent. ${ }^{51}$

Unfortunately, this approach raises problems very similar to those just discussed. In any case where a liability rule is appropriate, most parties will be equally unable to give proper consent to any other terms, so the effect will be much the same as if the terms adopted under the merit-good standard had been made mandatory. ${ }^{52}$ Moreover, while the merit-good analyst may consider his or her selected terms to be well worth the extra price, if buyers cannot be induced to share the analyst's perspective they may stubbornly refuse to pay the higher price. If so, the use of substantive criteria not linked to buyers' actual preferences will again end up pricing some buyers out of the market, thus raising all the problems discussed in the preceding subsection. In some cases, of course, the merit-good analyst might believe that it is better for buyers to do without the product, rather than purchase it without the meritorious terms. For many goods, though-and especially for "necessities"- the argument that buyers would be better off without the product is difficult to defend.

More fundamentally, any merit-good argument requires some substantive test by which the merit of any proposed merit good can be assessed. That is, the merit-good analyst must be able to say why certain contract terms are meritorious, and why their merit outweighs any higher prices that may accompany them. The analyst might of course defend his or her chosen terms by using one of the substantive criteria already discussed in this section. For example, the analyst might argue that the benefits of the chosen terms outweigh their extra costs when benefits are evaluated

61 This use of merit-good arguments, and its relation to paternalism, is discussed in Charny, 89 Mich L Rev at 1832-34 (cited in note 11).

\$2 Thus, most of this section's discussion of substantive criteria would apply a fortiori to non-waivable rules or inalienable entitlements. See note 8 . 
either by actual consumer preferences or by those of ideal consumers. If the analyst takes this position, however, the merit-good argument adds nothing to the two substantive criteria already discussed.

To provide a distinctive substantive criterion, the merit-good analyst must have a theory of merit that does not depend on consumer preferences (either actual or ideal). In effect, the analyst needs a theory of the "just term," analogous to medieval theories of the "just price." However, such theories are notoriously difficult to develop and defend, and few such theories have been put forward in the contracts literature. ${ }^{53}$ The principle of free contract is by now so widely accepted that most modern observers would regard almost any term adopted with each party's full consent as just. As a result, when modern observers are forced to select contract terms on behalf of parties who are unable to consent, it is difficult to find any substantive criteria to fall back upon other than criteria based on the parties' own preferences, either actual or ideal. It is easy to imagine specific benefits which a merit-good analyst might put forward as having value independently of parties' actual preferences-for example, the value of being protected against crushing losses that would leave one unable to pursue one's life projects. It is harder to suggest any non-preference-based criterion for deciding whether or when such a benefit is worth whatever price the parties would have to pay.

d) Reasonable expectations. A different approach would evaluate the content of possible obligations by testing them against the expectations of the other party to the contract. This is the essence of the "reasonable expectations" doctrine often applied to insurance contracts and, with increasing frequency, to other standard form contracts as well. ${ }^{54}$ An analogous expectations-based criterion is sometimes used in products liability cases, where courts

${ }^{63}$ For discussions of the difficulties inherent in "just price" or "just term" theories, see F. H. Buckley, Three Theories of Substantive Fairness, 19 Hofstra L Rev 33 (1990); Randy E. Barnett, A Consent Theory of Contract, 86 Colum L Rev 269, 283-86 (1986). See also Gordley, 69 Cal L Rev 1587 (cited in note 36).

st For discussions of this doctrine, see Robert E. Keeton, Insurance Law Rights at Variance with Policy Provisions, 83 Harv L Rev 961, 961-77 (1970); Kenneth S. Abraham, Judge-Made Law and Judge-Made Insurance: Honoring the Reasonable Expectations of the Insured, $67 \mathrm{Va}$ L Rev 1151 (1981); W. David Slawson, The New Meaning of Contract: The Transformation of Contracts Law by Standard Forms, 46 U Pitt L Rev 21 (1984). The reasonable expectations doctrine is discussed at more length in Section II.B.3. 
determine whether a product is defective by asking whether it provides the level of safety that a reasonable consumer would expect. ${ }^{\mathrm{ss}}$

However, a standard based on "reasonable expectations" is ambiguous between two very different concepts: what parties actually expect, and what it would be reasonable for them to expect. The problems with any expectations-based standard depend on just how this ambiguity is resolved. If reasonable expectations are defined by whatever parties actually expect-a kind of social science fact-then, in principle, such expectations could be discovered by psychological tests or consumer surveys. In many cases, though, the contested obligation concerns some relatively unlikely contingency that most parties would not consciously consider prior to purchase. In these cases, presuming that the parties have any expectations at all (and then attempting to "discover" those expectations through tests or surveys after the fact) is more than a little problematic. ${ }^{\mathrm{s}}$

Partly for this reason, the ambiguity in the concept of "reasonable expectations" is often resolved in favor of a normative interpretation based on what would be reasonable for consumers to expect. This normative conception avoids the difficulties associated with consumer tests and surveys, but it introduces other difficulties associated with whichever normative criterion is used to decide what expectations would be reasonable. For example, if it is decided that buyers should reasonably expect efficient contract terms, but should not have to be on their guard against inefficient terms, the reasonable expectations approach reduces to the efficiency analysis described earlier. If some other substantive criterion is used to decide what expectations are reasonable, the reasonable expectations approach reduces to whichever substantive criterion is adopted.

Significantly, when courts employ a "reasonable expectations" standard they usually end up invoking some other substantive criterion to give content to that standard. In insurance law, for example, when the substance of an insurance contract seems otherwise reasonable to the courts, they generally rule that reasonable consumers should have expected the contested terms. When the substance of the contract seems unreasonable to the courts, they rule

${ }^{85}$ Barker v Lull Engineering Co., Inc., 20 Cal 3d 413, 134 Cal Rptr 225, 573 P2d 443, 452 (1978).

so But not without its defenders. For a recent defense of an approach to the selection of default rules which looks to the parties' "tacit assumptions," see Barnett, 78 Va L Rev 821 (cited in note 11). 
that the unreasonable terms could not have been reasonably expected by consumers. ${ }^{57}$ Similarly, in products liability law many courts have adopted an efficiency test to define what consumers may reasonably expect, by ruling that a reasonable consumer is entitled to expect exactly the level of safety it would be efficient for sellers to provide. ${ }^{58}$ As one commentator concluded, "[b]urdening a product defect analysis with the conceptual baggage of the hypothetical ordinary consumer adds essentially nothing of substance to a straightforward risk-utility balancing approach."

In short, judicial reliance on such ambiguous phrases as "reasonable expectations" or "substantive unconscionability" has done little to advance our understanding of the substantive criteria courts might use in evaluating challenged obligations under a liability rule. The efficiency criterion continues to receive a good deal of attention, both from its supporters and its critics, but alternatives to an efficiency criterion remain woefully undeveloped. The remaining two subsections document this problem in more detail by examining a recurring substantive issue: the trade-off between higher prices and more favorable terms.

3. Higher prices vs. more favorable terms.

The economic literature on unconscionability has often noted that requiring more favorable terms might make products unduly expensive. For example, Arthur Leff analogized the regulation of contract terms to the regulation of product quality, warning that "[i]n certain situations that would have the same effect as some building codes: the cheapest one can get is more expensive than one can afford." ing the merits of contested obligations according to an efficiency criterion, under which the amount buyers gain from more favorable terms is measured by their willingness to pay. If the buy-

\footnotetext{
${ }^{87}$ See Abraham, $67 \mathrm{Va}$ L Rev at 1166 (cited in note 54) ("[T] much more with the substance of coverage than with the expectations of the insured."). See also the text accompanying notes 112-13.

ss Sheila L. Birnbaum, Unmasking the Test for Design Defect: From Negligence [to Warranty] to Strict Liability to Negligence, 33 Vand L Rev 593, 614-18 (1980).

ss Id at 615.

${ }^{\circ 0}$ Arthur Allen Leff, Contract as Thing, 19 Am U L Rev 131, 155 (1970). Most other writers who approach unconscionability from an economic perspective have made similar observations. See Buckley, 19 Hofstra L Rev at 62-63 (cited in note 53); Epstein, $18 \mathrm{~J}$ L \& Econ at 305-15 (cited in note 6); M. J. Trebilcock, The Doctrine of Inequality of Bargaining Power: Post-Benthamite Economics in the House of Lords, 26 U Toronto L J 359, 381-84 (1976).
} 
ers' willingness to pay exceeds the sellers' losses, the accompanying price increase will never exceed the buyers' willingness to pay, so buyers should never be priced out of the market. ${ }^{61}$

Strangely, this trade-off between more favorable terms and higher prices is almost completely disregarded in most non-economic analyses of unconscionability. For example, Todd Rakoff's otherwise comprehensive article relegates Leff's concern, and the choice between less favorable terms and higher prices generally, to a single sentence in a footnote. ${ }^{62}$ This trade-off between more favorable terms and higher prices is also ignored in the more extensive writings of John Murray ${ }^{63}$ and David Slawson. ${ }^{64}$

While several explanations for this lacuna are possible, I suggest that it may result from a failure to appreciate the difference between property rules and liability rules. That is, the choice between less favorable terms and higher prices can indeed be ignored as long as the unconscionability problem in question is one that can appropriately be governed by a property rule. For example, suppose that X's contract clearly states that the warranty lasts for only three days-but suppose that $\mathrm{X}$ stops $\mathrm{Y}$ from reading the contract by lying about its contents, assuring him that the warranty lasts for three years. As X can remove this impediment simply by not lying, lies-like classic gun-to-the-head duress-are good candidates for the application of a property rule. Moreover, a property rule allows the court to refuse to enforce X's three-day limit without having to decide whether a longer warranty would be worth the higher price $\mathrm{X}$ would have to charge. Under a property rule, if $\mathrm{X}$ wants to enforce any particular time limit she must negotiate with $\mathrm{Y}$ directly, without misleading him. As long as there are no other impediments to proper consent, $Y$ can then decide for himself whether a longer warranty is worth whatever price $X$ would charge for it, thus freeing the court from this decision. In

62 See Craswell, 43 Stan L Rev at 372-84 (cited in note 46).

22 Todd D. Rakoff, Contracts of Adhesion: An Essay in Reconstruction, 96 Harv L Rev $1173,1208 \mathrm{n} 125$ (1983) ("Leff's fear that government will consistently err on the side of socializing too many risks ... seems to me unsubstantiated.").

6s John E. Murray, Jr., Unconscionability: Unconscionability, 31 U Pitt L Rev 1 (1969); Roundtable Discussion of Unconscionability, Etcetera, 31 U Pitt L Rev 547 (1970); John E. Murray, Jr., Section 2-207 of the Uniform Commercial Code: Another Word About Incipient Unconscionability, 39 U Pitt L Rev 597 (1978); John E. Murray, Jr., The Standardized Agreement Phenomena in the Restatement (Second) of Contracts, 67 Cornell L Rev 735 (1982).

- Slawson, 46 U Pitt L Rev 21 (cited in note 54); W. David Slawson, Standard Form Contracts and Democratic Control of Lawmaking Power, 84 Harv L Rev 529 (1971); W. David Slawson, Mass Contracts: Lawful Fraud in California, 48 S Cal L Rev 1 (1974). 
short, wherever a property rule can be employed, economists' instinctive concern with the trade-off between more favorable terms and lower prices can safely be ignored by the courts.

Significantly, many of the writers who do not address this trade-off implicitly assume that they are analyzing a case where a property rule can be employed. The following excerpt is illustrative:

A seller of a product which is accompanied by a standard form can make a buyer's expectations on any point as clear as the seller wants them to be. The seller could clearly advertise what a buyer should expect, for example, or he could clearly state what the buyer was getting in a standard form which the seller took steps to insure was actually read and understood by the buyer before the buyer entered into the purchase contract. $^{65}$

As long as the seller can achieve this goal at a sufficiently low cost for every term she might someday wish to enforce, the courts can protect buyers with a property rule.

If, however, it is prohibitively expensive to achieve such clarity with respect to every term the seller might want to enforce, a different analysis is required. The seller's failure to achieve such clarity can still be treated as invalidating the buyer's proper consent-I take no position on that question here-but now the law's response must take the form of a liability rule rather than a property rule. Under a liability rule, the court will be choosing enforceable terms on behalf of parties who, by hypothesis, cannot practicably give their own consent to all of the terms in question. Whenever the court must select terms for parties who cannot give their own consent, the trade-off between more favorable terms and higher prices can no longer be ignored.

os Slawson, $48 \mathrm{~S} \mathrm{Cal} \mathrm{L} \mathrm{Rev} \mathrm{at} \mathrm{21-22} \mathrm{(cited} \mathrm{in} \mathrm{note} \mathrm{64)(footnote} \mathrm{omitted).} \mathrm{A} \mathrm{similar}$ assumption is sometimes made even by those who approach unconscionability from an economic perspective, as the following excerpt illustrates:

Under current contract and commercial law, the existence of imperfect information is a necessary but generally not sufficient condition for legal intervention. An additional prerequisite is the existence of substantively unfair contract terms. The argument to this point, however, shows that imperfect information should constitute a sufficient ground for intervention.

Alan Schwartz and Louis L. Wilde, Intervening in Markets on the Basis of Imperfect Information: A Legal and Economic Analysis, 127 U Pa L Rev 630, 639 (1979) (footnote omitted; emphasis added). If Schwartz and Wilde mean that courts can "intervene" without any analysis of the substance of the challenged contract terms, they must be relying on an assumption similar to that stated in the text. 


\section{Reliance on pre-existing default rules.}

The reluctance of many analysts to address this trade-off may also be due to the belief that whenever proper consent to some clause is lacking, the courts can simply treat the contract as though it were silent on that point. As noted earlier, ${ }^{66}$ when a contract fails to address certain points, the law often provides a governing "default rule." These same default rules could also be used to govern cases where one party's form purports to address some topic, but without the other party's proper consent. ${ }^{67}$ Using pre-existing default rules in this way might seem to eliminate the need for courts to select their own substantive criterion for deciding which obligations are reasonable and which are not. In particular, it might free courts from having to decide which favorable terms are worth a higher price.

However, this apparent advantage is largely illusory. First, default rules are not always chosen for their reasonableness. As Ayres and Gertner put it, some default rules are "penalty defaults" which were never intended to be left in force, but were instead designed to induce one party or the other to specify their wishes more explicitly. ${ }^{68}$ For example, if a contract for a credit sale is silent about whether the seller retains a security interest in the good sold, the default rule is that no such security interest is created. ${ }^{69}$ Surely this default rule was not selected because the drafters thought that security interests were unreasonable, or that most buyers would prefer to make an unsecured purchase at a higher price. Instead, the function of this default rule is merely to induce sellers who want security interests to explicitly provide for them. An explicit specification removes any doubt about the seller's wishes by clearly signalling her intent, both to the buyer and to any subsequent reviewing court.

Penalty default rules such as these should not be used as the standard of substantive reasonableness under a liability rule. If a liability rule is being applied, it must be because most sellers have no practicable way of obtaining buyers' proper consent to certain

See Section I.A.3.

${ }^{67}$ For examples of this argument, see Rakoff, 96 Harv L Rev at 1181-83, 1209-10 (cited in note 62); Slawson, $46 \mathrm{U}$ Pitt L Rev at 45-46 (cited in note 54); Robert Dugan, The Application of Substantive Unconscionability to Standardized Contracts-A Systematic Approach, 18 New England L Rev 77, 87-95 (1982-83).

s See text accompanying notes 22-25.

6a The UCC does create an implied security interest in certain circumstances, but these are not relevant to the situation described in the text. See $\$ 2-507(2)$, § 2-711(3) (ALI 1972). 
terms. If the courts respond to this lack of consent by enforcing the "no security interest" default rule, the product will have to be sold without a security interest or not be sold at all. This outcome might be justifiable if the courts or legislature had already determined that most buyers would be better off paying a higher price and taking the product free of a security interest or else not buying the product at all. As discussed above, though, the "no security interest" default rule reflects no such judicial or legislative determination. This is why courts should not evaluate the reasonableness of a contested obligation by a pre-existing penalty default rule.

Of course, not all default rules are penalty default rules. When a pre-existing default rule does reflect a judicial or legislative determination that most buyers would prefer to pay a higher price for more favorable terms, courts may well be able to treat a clause that was not properly consented to as though the contract were silent on that point, thus bringing the pre-existing default rule into play. However, this use of default rules still requires some court or governmental agency to address the trade-off between more favorable terms and higher prices. If the default rule emerged from judicial precedent, we need confidence that the judges who created the precedent analyzed the relevant trade-off, and analyzed it correctly. If the default rule was created legislatively, we need a similar confidence in the analysis of the legislature. In short, the availability of a pre-existing default rule at most shifts the locus of the substantive evaluation required to implement a liability rule.

The fact that a liability rule requires this substantive evaluation to be performed somewhere by somebody is central to the choice between property rules and liability rules. As discussed in Section I.A, the principal drawback of a property rule is that it requires each party to obtain the other's proper consent, which may sometimes be impracticable, or even impossible (depending on the requirements of proper consent). However, the principal drawback of a liability rule is that it requires the courts-or, we might now add, it requires somebody - to decide which obligations are reasonable and which are not. The more difficult it is for courts and other agencies to conduct this evaluation, and the greater the harm that would result from an erroneous evaluation, the more the balance tips in favor of property rules rather than liability rules.

However, a third alternative must also be considered. If the costs of a substantive evaluation are too high to make a liability rule attractive, but the costs of obtaining proper consent are too high to make a property rule attractive, the third possibility is to 
lower the requirements for obtaining "proper" consent. That is, the court could simply enforce the contract as written, by finding that Y's consent was properly obtained.

To assess the advantages and disadvantages of this approach, we must now look more closely at the definition of proper consent. The following section argues that the rules for determining whether Y properly consented should depend on whether the nextbest alternative involves a property rule or a liability rule. In terms of the decision tree depicted in Figure 1, the initial choice between the upper and lower path should depend in part on just to which option the lower path will lead.

\section{Defining "Proper" Consent}

Most theories of what I have called proper consent focus on the voluntariness of the actor's choice, and the actor's knowledge about the consequences of his choice. However, the concepts of "voluntariness" and "adequate knowledge" are notoriously difficult to define. Compare the following cases:

(1) $\mathrm{Y}$ is healthy, but $\mathrm{X}$ threatens to shoot $\mathrm{Y}$ unless he agrees to have his leg amputated.

(2) $\mathrm{Y}$ is drowning (through no one's fault), and $\mathrm{X}$ refuses to rescue him unless he agrees to have his leg amputated.

(3) Y's leg is injured in an accident (through no one's fault), and he will die unless he agrees to let $\mathrm{X}$ amputate his leg.

In each case, Y's choice to have his leg amputated is "voluntary" in the sense that $X$ prefers that choice to the only available alternative. Yet all would release $Y$ from his choice in case (1), many would release him in case (2), and no one would release him in case (3).

Philosophers have offered several theories to distinguish cases such as these. ${ }^{70}$ For example, it could be argued that Y's choice is coerced, or his consent is not "proper," if and only if the alternative to accepting X's offer would make $X$ worse off relative to a baseline defined by Y's moral or legal rights (for example, a right not to be shot). ${ }^{71}$ Under this approach, Y's choice is clearly coerced in case (1), and the voluntariness of his choice in case (2) depends

70 See generally Alan Wertheimer, Coercion (Princeton, 1987); J. Roland Pennock and John W. Chapman, eds, Coercion (Aldine-Atherton, 1972).

${ }^{71}$ See Robert Nozick, Coercion, in Sidney Morgenbesser, Patrick Suppes and Morton White, eds, Philosophy, Science and Method: Essays in Honor of Ernest Nagel 440 (St. Martin's, 1969). 
on whether $\mathrm{Y}$ has a legal or moral right to be rescued by $\mathrm{X}$. Other baselines are also possible-for example, whether the alternative to accepting $\mathrm{X}$ 's offer leaves $\mathrm{Y}$ worse off than $\mathrm{Y}$ had expected $\mathrm{X}$ to leave him before he learned of X's actual proposal, or worse off than most people in Y's position would be left by most X's. ${ }^{72}$ Other theories invalidate $\mathrm{Y}$ 's consent only when $\mathrm{X}$ affirmatively causes the condition that make the alternative unattractive to $Y$ (though not necessarily by violating $Y$ 's rights), thus requiring some distinction between affirmatively causing harm and merely failing to prevent it. ${ }^{73}$

In the legal literature, those who oppose judicial invalidation of contracts usually do so by defending one of the more easily satisfied philosophical theories of consent, while those who support judicial intervention do so on the basis of one of the more demanding theories. ${ }^{74} \mathrm{My}$ contention, though, is that whichever philosophical theory one accepts is irrelevant to deciding whether a contract ought to be enforced whenever the alternative to enforcement is a liability rule. Liability rules do nothing to change Y's alternative to whatever terms the court deems reasonable. Thus, if Y's only alternative is so bad that it invalidates his consent to $X$ 's contract, it should also invalidate his consent to the terms selected by the court.

For example, suppose that $\mathrm{X}$ has a monopoly over some important product, and uses that monopoly to force a high price or some other burdensome contract term on $Y$. It might then be asked whether Y's choice between accepting X's terms or doing

73 Wertheimer, Coercion at 207 (cited in note 70) (referring to these alternative baselines as the "phenomenological" and "statistical" respectively).

${ }^{73}$ For discussions of tests incorporating this standard as one element, see David Zimmerman, Coercive Wage Offers, 10 Phil \& Pub Aff 121 (1981); Lawrence A. Alexander, Zimmerman on Coercive Wage Offers, 12 Phil \& Pub Aff 160 (1983); David Zimmerman, More on Coercive Wage Offers: A Reply to Alexander, 12 Phil \& Pub Aff 165 (1983).

There are also instrumental or utilitarian theories of consent. For example, some economists have objected to duress not because it violates the victim's rights but because it gives victims an incentive to improve their powers of self-defense, triggering an "arms race" which ultimately benefits neither side. See Cooter and Ulen, Law and Economics at 254-56 (cited in note 39); Gordon Tullock, The Welfare Costs of Tariffs, Monopolies, and Theft, 5 Western Econ J 224, 228-31 (1967).

${ }^{74}$ Explicit discussions of these theories in the legal literature include Charles Fried, Contract as Promise ch 7 (Harvard, 1981); Michael J. Trebilcock, The Limits of Freedom of Contract ch 3 (Harvard, forthcoming 1993) (on file with U Chi L Rev); Scott Altman, Divorcing Threats and Offers (unpublished manuscript, 1992) (on file with U Chi L Rev); Peter Benson, Abstract Right and the Possibility of a Nondistributive Conception of Contract: Hegel and Contemprary Contract Theory, 10 Cardozo L Rev 1077 (1989); Epstein, 18 J L \& Econ at 295-97 (cited in note 6); Anthony T. Kronman, Contract Law and Distributive Justice, 89 Yale L J 472, 495-97 (1980). 
without the product make Y's consent to X's terms less than truly voluntary. If the absence of an alternative supply is deemed to invalidate Y's consent, $\mathrm{Y}$ can hardly be protected with a property rule, for that would prevent $\mathrm{X}$ from ever making an enforceable contract with Y (or with anyone else). ${ }^{75}$ Instead, if X's monopoly invalidates $Y$ 's consent, $Y$ will have to be protected with a liability rule. Under a liability rule, $\mathrm{X}$ may be prevented from enforcing an unreasonable price or other unreasonable terms, but she will still be allowed to insist on prices and terms that a reviewing court deems reasonable.

In such a case, the legal definition of consent will not affect the voluntariness of Y's decision. If the law refuses to recognize X's monopoly as invalidating Y's consent, $\mathrm{Y}$ will be left with a choice between doing without the product in question or accepting X's terms. If the law does recognize X's monopoly as invalidating Y's consent, $Y$ will be left with a choice between doing without the product or accepting whatever terms the court deems reasonable. Thus, no matter how the law defines consent, $Y$ will still be put to a choice between accepting terms drafted by someone else, or doing without an essential product. The only effect of the definition of proper consent is to determine whose terms $\mathrm{Y}$ has a choice of accepting: terms drafted by $\mathrm{X}$, or terms approved by the court.

Notice that this argument does not apply when the alternative to enforcing the contract is protecting $\mathrm{Y}$ with a property rule. Whenever a property rule is an appropriate response-typically, in cases where $\mathrm{X}$ can eliminate the alleged impediment to proper consent-judicial intervention can change the quality of Y's consent, by inducing $X$ to remove the impediment. Thus, whenever a property rule can be used, the philosophical theories described above may well be relevant to deciding which of those impediments that can be removed ought to be removed. Significantly, though, many of these philosophical theories identify impediments which cannot be removed by the other party: impediments such as the absence of any alternative rescuers, or the victim's poverty. As these impediments will still be present even if the court substitutes its own

75 See Slawson, $48 \mathrm{~S} \mathrm{Cal} \mathrm{L} \mathrm{Rev} \mathrm{at} \mathrm{47-48} \mathrm{(cited} \mathrm{in} \mathrm{note} \mathrm{64)} \mathrm{("When} \mathrm{General} \mathrm{Motors}$ Corporation deals with me, it will always have the superior bargaining power. If disparity of bargaining power were sufficient to invalidate a contract, General Motors and I could never make a valid contract."). A property rule might be justified if the law sought to break up monopolies wherever they existed, a process which could be encouraged by refusing to enforce any contracts made by a monopolist-but the law has never taken so strong an antimonopoly stance. See note 97 (discussing the possibility of a similar policy toward horizontal collusion). 
terms for those of the original contract, the victim's consent will be equally invalid (under these theories) whether the court intervenes or not. The invalidity of the buyer's consent therefore gives no basis for choosing between enforcing the contract as written and protecting the victim with a liability rule.

\section{Political process values.}

It might be argued that the law's definition of consent should take account of a different set of philosophical values: the values served by judicial or political processes, rather than the values served by private consent. That is, as coupling a liability rule with a more stringent definition of consent will result in more obligations being selected by the court rather than by $\mathrm{X}$, it might be argued that Y's ability to participate in the judicial process serves an important process value. Similarly, if the substantive evaluations required under a liability rule are made by a legislature, it might be argued that $\mathrm{Y}$ participated in the legislative decision through the electoral process, and that this legislative decision should be preferred over a simple enforcement of X's terms. ${ }^{76}$ In other words, if the definition of proper consent under a liability rule serves only to reallocate decisionmaking authority between $\mathrm{X}$ and some governmental body, the alternative substantive outcomes are not the only possible bases for choosing between them. Instead, the process values served by the relevant governmental bodies might argue in favor of giving the decision to the governmental body.

However, the choice is not simply a choice between democratically-chosen terms and terms unilaterally drafted by X. Many governmental institutions are far from democratic, and even terms drafted "unilaterally" by X are in reality the result of a complex interplay of private and governmental forces. ${ }^{77}$ Thus, whether the

\footnotetext{
76 For a suggestion of an argument along these lines, see Rakoff, 96 Harv L Rev at 1238-43 (cited in note 62); Slawson, 84 Harv L Rev at 533-37 (cited in note 64). The argument that $\mathrm{Y}$ directly participates in the judicial process is of course somewhat attenuated in this day of class actions and mass litigation, especially when one considers the possible precedential effect of one litigated case on the standardized forms used by thousands of other consumers not party to the litigation. Nonetheless, the decisions of the courts and litigators still might serve political process goals under some theory of indirect representation as applied to the litigation process. For a review of these theories, see Robert G. Bone, Rethinking the "Day in Court" Ideal and Nonparty Preclusion, 67 NYU L Rev 193 (1992).

${ }^{77}$ As a number of authors have noted, even the "unregulated market" reflects a large degree of state activity to define property rights, police against theft, enforce contracts, and so on. See, for example, Morris R. Cohen, The Basis of Contract, 46 Harv L Rev 553 (1933);
} 
enforceable obligations are selected by $\mathrm{X}$ or by a federal regulatory agency, every $\mathrm{Y}$ will still have played some role in the political processes which permitted that obligation to be selected, but the role played by most Y's will have been extremely remote. I know of no process-based theory sufficiently fine-tuned to make an argument for either of these highly attenuated roles over the other on the basis of either's contribution to personhood or autonomy.

\section{Incentives and institutional competence.}

How, then, should the law define "proper" consent in cases in which invalidating X's contract would trigger a liability rule? My suggestion is that philosophical theories about the validity of Y's consent can at most supply a necessary but not sufficient condition for invalidating X's contract. To invalidate X's contract, it should also be necessary (and perhaps even sufficient) to believe the terms the courts will enforce are superior to X's terms, according to whatever criterion of substantive reasonableness one adopts. ${ }^{78}$ In other words, the decision should ultimately rest on a comparison between the incentives and expertise governing X's choice of terms, and the incentives and expertise governing the court's. (I will refer to these factors collectively as considerations of "institutional competence.")

For example, if $\mathrm{X}$ has a monopoly and $\mathrm{Y}$ is contesting the price $\mathrm{X}$ charged, economic theory provides many reasons for suspecting that X's price will not be efficient. This suggests that if economic efficiency is accepted as the relevant substantive criterion, the authority to set prices should be given to the courts rather than to $X$. In that case, $X$ 's monopoly should be treated as invalidating Y's consent, triggering a liability rule and allowing a court to review the price's reasonableness.

There may, however, be reasons to think that judicial regulation of prices is more likely to aggravate matters. As noted earlier, the record of local regulatory agencies in this regard does not inspire confidence. ${ }^{79}$ If we do not expect courts to adequately set prices, we should be more reluctant to treat X's monopoly as invalidating Y's proper consent. That is, even if philosophical theories of voluntariness would not recognize Y's consent as valid, the law ought to enforce X's contract anyway, rather than allowing the

Duncan Kennedy and Frank Michelman, Are Property and Contract Efficient?, 8 Hofstra L Rev 711 (1980).

${ }^{78}$ See Section I.B.2.

79 See note 36 . 
courts to enforce an equally involuntary but substantively worse price. In short, a showing that Y's consent was in some respect improper may perhaps be a necessary condition for invalidating $X$ 's contract, but it can hardly be sufficient.

Indeed, it is far from clear that the involuntariness of Y's consent should even be a necessary condition for invalidating X's contract. Suppose, for example, that $X$ has a monopoly over some product, but that it is no real hardship for $\mathrm{Y}$ to do without the product rather than agree to X's terms. Suppose, though, that we are also convinced that judicially-determined prices will be substantively better than those picked by the monopolist. Can the monopolist nonetheless claim a moral right to enforce her price, as long as Y's agreement to that price was valid under all of the philosophical theories of consent? (Is the regulation of cable television rates morally illegitimate because cable television is not a necessity?) The growth of economic regulation over the last sixty years makes this absolute libertarian constraint difficult to defend. But if this constraint is rejected, the ability of courts to set superior prices becomes both a necessary and a sufficient condition for invalidating X's contract. That is, X's monopoly should be treated as invalidating $Y$ 's consent if and only if we think courts can do a better job at setting prices than $\mathrm{X}$ can. Once this view is accepted, the definition of proper consent depends entirely on the relative incentives and institutional expertise.

The case for defining "proper consent" on the basis of incentives and institutional expertise can be seen even more clearly by considering an example where $\mathrm{X}$ is a monopolist and $\mathrm{Y}$ has challenged some non-price term, such as the scope of X's warranty. Most philosophical theories of voluntariness would investigate the validity of Y's consent without considering which terms $\mathrm{X}$ objects to. However, the ability of courts to improve on X's non-price terms is likely to be less than their ability to improve on X's prices, for monopolists do not have as many incentives to distort the non-price terms of their contracts. Indeed, the monopolist's incentive is normally to offer the most attractive non-price terms she can think of, the better to gouge her customers by charging them an even higher price.

To be sure, in some cases a less efficient non-price term might alter the pattern of demand in a way that increases the monopolist's profits, thus giving her an incentive to use a less efficient non- 
price term. ${ }^{80}$ In these cases, however, the term that maximizes her profits may actually be more generous to consumers than an efficient term would be (though it will be coupled with an extremely high price), so it is not necessarily the most unfavorable non-price terms that ought to be challenged under this rationale. ${ }^{81}$ More important, even when a monopolist does have an incentive to select inefficient non-price terms, altering the monopolist's non-price terms without altering her ability to charge a monopoly price will not necessarily leave her customers better off. ${ }^{82}$

Given these difficulties, it would not be implausible to decide that courts should not attempt to improve on a monopolist's nonprice terms in cases where the only impediment to consent is the seller's monopoly. That is, courts could treat X's monopoly as not invalidating Y's consent to any of X's non-price terms-even if we have also concluded that X's monopoly should be treated as invalidating Y's consent to her price terms, because we think courts can do a better job improving on a monopolist's prices. In other words, it might make perfect sense to adopt a different definition of "proper consent" depending on whether a price or a non-price term is being challenged.

Admittedly, if proper consent is to be defined in so pragmatic a fashion, it might be better not to call the resulting concept "consent," or at least to qualify it as "consent for legal purposes" or "consent for purposes of contract law." A very standard view-so standard that it is rarely stated explicitly-holds that true consent can be defined independently of the consequences the law attaches

\footnotetext{
so For a survey of the economic literature on this point, see Richard Schmalensee, Market Structure, Durability, and Quality: A Selective Survey, 17 Econ Inquiry 177 (1979). For a non-technical discussion, see Kennedy, $41 \mathrm{Md} \mathrm{L}$ Rev at 617-18 (cited in note 42).

${ }^{81} \mathrm{Katz}, 21$ RAND J Econ at 530-31 (cited in note 29). A similar observation has been made concerning damage remedies: in some cases, welfare might be improved by forcing monopolists to accept a lower limit on their damage liability than the monopolists themselves would choose, if a large liquidated damage clause would assist the monopolist in sorting its customers to facilitate profitable price-discrimination. Jason Scott Johnston, Strategic Bargaining and the Economic Theory of Contract Default Rules, 100 Yale L J 615, 66164 (1990); Ian Ayres and Robert Gertner, Strategic Contractual Inefficiency and the Optimal Choice of Legal Rules, 101 Yale L J 729, 744 (1992).

${ }^{82} \mathrm{Katz}, 21$ RAND J Econ at 531-33 (cited in note 29). For similar models addressing the welfare effects of regulating the monopolist's choice of product quality (rather than "contract quality")-all reaching similarly pessimistic conclusions about the difficulty of determining whether or when such regulations will improve consumer welfare-see David Besanko, Shabtai Donnenfeld, and Lawrence J. White, Monopoly and Quality Distortion: Effects and Remedies, 102 Q J Econ 743 (1987); Eytan Sheshinski, Price, Quality and Quantity Regulation in Monopoly Situations, 43 Economica 127 (1976); A. Michael Spence, Monopoly, Quality, and Regulation, 6 Bell J Econ 417 (1975).
} 
to a lack of consent, and that the connection between the two runs entirely in one direction. That is, on this view the definition of proper consent may tell us when the law ought to impose certain consequences, but the consequences the law imposes are not thought to affect the definition of proper consent. In this traditional view, consent is a primitive concept which can be defined by a moral theory wholly external to the law.

Whatever terminology is employed, the key point is that "consent for purposes of contract law" is precisely what is at stake in contracts cases. That is, the ultimate concern of the legal doctrines analyzed in this paper is not consent as an abstract or ideal concept, but whether consent is lacking in some way that ought to make the resulting contract unenforceable, thereby triggering the application of either a property rule or a liability rule. Given this concern, the definition of consent for purposes of contract law can legitimately take into account the costs and other difficulties of implementing a property or liability rule. If the law's best response to some consent problem is a liability rule rather than a property rule, and if we think courts applying a liability rule would do worse than $\mathrm{X}$ in selecting reasonable obligations, the problem in question should not be treated as invalidating Y's consent.

3. Substantive tests in the definition of consent.

One further complication must be introduced. Under some definitions of consent, the courts may need to evaluate the reasonableness of a contested obligation simply to determine whether Y's consent was proper. These definitions of consent therefore require courts to evaluate the substance of the challenged obligation even if a property rule will govern. This means that the relevance of incentives and institutional expertise is not limited to those cases where lack of consent will trigger a liability rule. Whenever a proposed definition of consent requires the court to exercise substantive judgment to decide whether consent is lacking, the demands placed on the court will be the same regardless of whether a liability rule or a property rule is in force. As a consequence, questions about the court's institutional expertise will be relevant to deciding whether to accept the proposed definition of consent.

a) Unreasonable terms as evidence of lack of consent. If Y's claim that he never consented is based on an impediment to proper consent that cannot be proved directly, the substantive reasonableness of X's contract terms may be relevant as indirect evidence of the alleged impediment to consent. For example, if $\mathrm{Y}$ 
claims that $\mathrm{X}$ lied to him but $\mathrm{X}$ denies having lied, the reasonableness or unreasonableness of the resulting contract might help a court decide which party to believe. If the contract is so onerous that few people would agree to it unless they had been tricked, that makes Y's story more plausible. The unreasonableness of the resulting contract might also be evidence of some other impediment to proper consent, such as duress or ignorance. Indeed, in competency cases part of the court's evaluation of competency consists of evaluating the substantive merits of the contract the party signed. ${ }^{\text {s3 }}$

Under this approach to identifying the absence of consent, it is still possible for courts to protect $\mathrm{Y}$ with what would nominally be a property rule. That is, once the court decides that $\mathrm{X}$ probably did lie to $Y$, the court could refuse to let $X$ enforce any obligations against $Y$, even obligations whose substance would otherwise seem perfectly reasonable. However, if the court invokes this property rule only after finding (in the course of resolving the conflicting testimony about X's lie) that X's proposed obligation was not reasonable, the net effect will be very similar to a liability rule. The court will still have had to incur all the administrative costs associated with evaluating the substance of the proposed obligation. Moreover, if the court errs in this evaluation, then desirable obligations will be improperly struck down or undesirable obligations will be improperly enforced..$^{84}$ Thus, questions of institutional competence and expertise are clearly relevant to this approach to defining consent, just as they are to any definition of consent that is coupled with a liability rule.

b) Unreasonable terms in the definition of proper consent. Under some definitions of proper consent, the substance of $X$ 's terms are relevant as part of the definition of consent, not merely as indirect evidence of some independently-defined impediment to consent. For example, it is sometimes argued that buyers who sign fine-print contracts consent to all reasonable terms contained in the fine print, but not to any unreasonable ones. ${ }^{86} \mathrm{In}$ -

${ }_{83}$ Milton D. Green, Proof of Mental Incompetency and the Unexpressed Major Premise, 53 Yale L J 271, 298-306 (1944). For a more recent and somewhat less skeptical review of the competency cases, see Alexander M. Meiklejohn, Contractual and Donative Capacity, 39 Case W Res L Rev 307, 352-56 (1988-89).

84 For a similar observation with respect to incompetency cases, see Alan Schwartz, A Reexamination of Nonsubstantive Unconscionability, $63 \mathrm{Va}$ L Rev 1053, 1077-78 (1977).

${ }^{8 s}$ See, for example, Karl N. Llewellyn, The Common Law Tradition: Deciding Appeals 370 (Little, Brown, 1960) (emphasis added): 
deed, this is a perfectly plausible interpretation of the "reasonable expectations" doctrine discussed earlier. ${ }^{88}$ The earlier interpretation of the doctrine was that buyers do not properly consent to any clauses hidden in fine print, but that reasonable fine-print clauses could still be enforced, because buyers are only protected by a liability rule. An equivalent way to characterize this result is to say that a property rule will be used to protect buyers against all terms they have not consented to, but buyers are deemed to have consented to any reasonable terms contained in the fine print. Under either characterization, all of the reasonable terms will be enforceable, and all of the unreasonable ones will not. ${ }^{87}$

This technique of building substantive evaluations into the definition of the entitlement to be protected has analogs in property and tort law. For example, nuisances are sometimes defined as an "unreasonable" interference with another's property, with the reasonableness of the interference to be determined by some form of cost-benefit analysis which balances X's gains from the interference against Y's losses. ${ }^{88}$ Under this definition, Y can be protected by a property rule rather than a liability rule, in the sense that any unreasonable taking by $\mathrm{X}$ can be strictly enjoined or penalized with severe sanctions. Obviously, though, courts implementing this property rule have to make many of the same determinations they would have to make if $\mathrm{Y}$ was given a broader entitlement against all interference, but was protected only by a liability rule. Under such a liability rule, courts have to measure Y's losses from every interference, in order to calculate Y's damage award. Under a

Instead of thinking about "assent" to boiler-plate clauses, we can recognize that so far as concerns the specific, there is no assent at all. What has in fact been assented to, specifically, are the few dickered terms, and the broad type of the transaction, and but one thing more. That one thing more is a blanket assent (not a specific assent) to any not unreasonable or indecent terms the seller may have on his form ....

${ }^{86}$ See text accompanying notes 54-59.

87 This equivalence is depicted in the decision tree in Figure 1, where there are two different paths leading to the "enforce as written" result. As long as the upper path (in which $Y$ is deemed to have properly consented) is chosen only when X's terms are substantively reasonable, the two paths are practically identical. To be sure, some authors distinguish between the symbolic import of (a) enforcing those terms of X's contract whose substance is deemed reasonable, and (b) refusing to enforce those terms, but enforcing identical obligations as part of the judge-made law to be applied after X's contract terms are ruled unenforceable. See, for example, Rakoff, 96 Harv L Rev at 1260 (cited in note 62). As my concern is entirely with the question of what obligations $\mathrm{X}$ may enforce against $\mathrm{Y}$, I will not distinguish between these two characterizations of the same outcome.

ss 4 Restatement (Second) of Torts $\$ \S 822,826-828$ (ALI, 1979). For a discussion, see Thomas W. Merrill, Trespass, Nuisance, and the Costs of Determining Property Rights, 14 J Legal Stud 13 (1985). 
property rule protecting against unreasonable interference, courts would normally have to measure both Y's losses and X's gains from each interference, in order to determine whether $Y$ 's entitlement had been infringed. ${ }^{80}$

Thus, whenever the courts employ a property rule to protect an entitlement which is itself defined by a "reasonableness" test, the informational demands are very similar to those associated with a liability rule. Moreover, the effect of such a rule will be the same as that of a liability rule: terms deemed reasonable by the courts will be enforceable, while terms deemed unreasonable will not be. It follows that proper consent should not be defined in this way unless we have some confidence in the ability of courts (or some other agency) to conduct such an evaluation: institutional competence should be dispositive in these cases as well. For the remainder of this Article, I will treat these definitions of consent as variations on a liability rule, regardless of how they are described.

\section{Applications}

Part I of this Article demonstrated that where the validity of Y's consent is questioned, the choice facing courts is not merely between enforcing and not enforcing the resulting contract. Instead, the law has three alternatives. The law can (a) declare Y's consent to be valid and enforce the contract without any judicial scrutiny of its substance, thus allowing the parties to create enforceable obligations without any change in their negotiating practices; (b) declare Y's consent invalid and protect $\mathrm{Y}$ with a property rule, thus forcing the parties to change their negotiating practices if they wish to create enforceable obligations; or (c) declare Y's consent invalid and protect $\mathrm{Y}$ with a liability rule. The third option abandons any reliance on the parties' own negotiating practices, and turns the selection of enforceable obligations over to the courts. Thus, Part I also argued that the definition of proper consent should be based entirely on pragmatic considerations whenever a liability rule is superior to a property rule. In other words, whenever option (c) dominates option (b), the choice between the two remaining options, (c) and (a), should be made by comparing the court's ability to select reasonable obligations with the incentives facing the party who drafted the contract.

\footnotetext{
${ }^{89}$ In certain cases, there may be proxies that would enable a court to evaluate the reasonableness of the interference without separately measuring Y's losses and X's gains. See Cooter, 84 Colum L Rev at 1533-36 (cited in note 3).
} 
In this portion of the Article, I survey the problems or conditions most often advanced as invalidating consent, discussing which of the three responses is most appropriate in each case. Of course, any number of factors might arguably invalidate a party's consent, and the discussion below does not pretend to be exhaustive. For convenience-although nothing of substance turns on this-I divide the possible problems into three categories: those involving inadequate alternatives to the offered terms; those involving inadequate information about the offered terms or the available alternatives; and those involving inadequate competence to process the information and decide between the offered terms and their alternatives.

\section{A. Inadequate Alternatives}

I refer to "inadequate alternatives," rather than "lack of choice," because cases involving a true lack of choice are exceedingly rare. Even a classic instance of duress at gunpoint leaves the victim a choice of sorts: sign the contract, or be shot. At the other extreme, even the mildest and most reasonable of offers could be said to involve a kind of a threat-"If you do not accept my offer, you'll be forced to fall back on whatever your next-best alternative is"-even though the next-best alternative might be no worse than buying a similar product at the same price from a seller one block away. Most philosophical definitions of consent thus require some way of deciding which alternatives are so unattractive, or so serious a violation of the buyer's rights, or so illegitimate according to some other criterion of legitimacy, as to justify the conclusion that a buyer who chooses to sign the contract rather than accept the alternative has not truly consented.90

\section{Duress and necessity.}

As noted earlier, duress at gunpoint is appropriately governed by a property rule rather than a liability rule. Courts can therefore enforce a rule against duress without having to evaluate the substance of the obligation $\mathrm{X}$ is attempting to enforce. As a consequence, questions about the ability of courts to conduct such evaluations are of little relevance in deciding whether duress should count as invalidating Y's consent.

Cases of physical or economic necessity without duress-cases in which $\mathrm{X}$ was not responsible for Y's necessity_present a harder

- See text accompanying notes 68-72. 
problem for most philosophical theories of consent. If $\mathrm{Y}$ will drown if he refuses to agree to X's contract, the unattractiveness of this alternative is every bit as great as in the gunpoint case. If $\mathrm{X}$ has no legal or moral duty to rescue $\mathrm{Y}$ from drowning, however, it is no longer true that the only alternative to $X$ 's contract also violates Y's legal or moral rights. Thus, to assess the validity of Y's consent in cases of economic or physical necessity, a philosophical theory of consent must specify more precisely the kinds of alternatives required for a valid act of consent.

My claim is that even a more fully-specified philosophical theory of consent would not settle the question of whether $\mathrm{Y}$ ought to be released from his contract in cases of economic or physical necessity. As noted earlier, if necessity is taken to invalidate Y's consent, $\mathrm{Y}$ needs the protection of a liability rule rather than a property rule, for there will usually be no way for X to cure Y's necessity and obtain proper consent. ${ }^{91}$ This means that deciding that Y ought to be "released" from his contract is really just deciding that $\mathrm{X}$ should be entitled to a price set by the court, rather than her own price. To be sure, if $X$ is the only person in a position to rescue $\mathrm{Y}$, her price will not be constrained by competition, and there may well be reason to prefer the court's price to X's. But if we believe that a court would for some reason set too low a price, thereby discouraging efficient rescues, ${ }^{92}$ this argument for preferring the court's price disappears.

\section{Monopoly.}

If $\mathrm{X}$ has a monopoly over some good or service that is not essential to $\mathrm{Y}$-say, a monopoly over electric toasters-the case no longer qualifies as one of economic or physical necessity. Y's alternatives will still be limited to accepting $X$ 's terms or doing without her product, but now the alternative of doing without X's product is a much less onerous option, which neither violates Y's legal rights nor exposes him to tragic consequences. Accordingly, most

91 See text accompanying notes 6-7. The situation is different if $\mathrm{X}$ unjustifiably caused $Y$ 's necessity by sabotaging his ship's rudder. In these cases, $Y$ could well be protected by a property rule, to deter $\mathrm{X}$ from creating the situation in which $Y$ 's proper consent can no longer be obtained.

92 For analyses of the optimal compensation for rescue services, see Buckley, 19 Hofstra L Rev at 40-48 (cited in note 53); Eisenberg, 95 Harv L Rev at 754-63 (cited in note 34); William M. Landes and Richard A. Posner, Salvors, Finders, Good Samaritans, and Other Rescuers: An Economic Study of Law and Altruism, 7 J Legal Stud 83 (1978). Possible reasons for being skeptical about the ability of courts (or of specialized regulatory commissions) to set an appropriate price are suggested in note 36. 
philosophical theories of consent would not treat Y's consent as invalid if the monopolized product is not a necessity.

Notice, though, that if there are institutional competence arguments for preferring the court's pricing of necessities; those arguments are likely to be as strong when X's product is not a necessity. In either case, $X$ 's monopoly position gives us reason to think the price set by $\mathrm{X}$ is not ideal. On the other hand, it should not be any harder for the court to set a reasonable price for electric toasters than it would be to set a reasonable price for food or rescue services. If anything, the case for judicial price-setting might actually be stronger in the case of non-necessities, for the consequence of an erroneous price is less severe (too few toasters, as opposed to too few rescue services). As far as considerations of institutional competence are concerned, therefore, the distinction between necessities and non-necessities is largely irrelevant.

Recall, too, that when $\mathrm{Y}$ challenges a non-price term, the institutional competence arguments for overriding $X$ 's contract are weaker. As noted in Part $I{ }^{93}$ monopolists often have no incentive to use inefficient non-price terms. Even when they do have such an incentive-or when the reasonableness of the monopolist's terms is judged by some criterion other than economic efficiency-requiring the monopolist to adopt more reasonable terms without taking away her ability to charge a monopoly price will not necessarily leave customers better off. ${ }^{94}$ Thus, while most philosophical theories of consent do not differentiate between consenting to a monopolist's price and consenting to non-price terms, this distinction could properly be part of a legal definition of proper consent. For non-price terms, as for price, the key distinctions are those that go to relative institutional competence, not those that rest on philosophical theories about the voluntariness of an agent's consent.

3. Inability to obtain better terms.

In many cases, $Y$ may have had the option of turning to several sellers other than $X$, but none will have offered terms better than X's. A buyer in this situation faces a choice formally identical to the one analyzed in the preceding subsections: accept the offered terms, or do without the product in question. From the standpoint of most philosophical theories of consent, the validity of Y's consent in this case might once again depend on whether the

\footnotetext{
is See text accompanying notes 75-77.

* See text accompanying notes 74-76.
} 
product in question is a necessity. When viewed from the standpoint of institutional competence, however, this case may present either a stronger or a weaker argument for intervention than cases in which $\mathrm{X}$ has a monopoly-depending on exactly why no seller is offering better terms.

a) Perfectly competitive markets. If buyers are perfectly informed and the market is perfectly competitive, the absence of better terms suggests that no buyer is willing to pay enough to make it profitable for sellers to offer the better term. If so, there is no justification for requiring sellers to offer better terms, and therefore no justification for treating Y's consent as invalid. Moreover, this conclusion holds whether or not the product in question is a necessity.

b) Collusion. If the absence of better terms results not from perfect competition, but from an agreement among sellers to all offer the same terms, ${ }^{96}$ the question is more difficult. Cases of collusion could be governed by a property rule in order to discourage inter-firm collusion. Refusing to enforce any collusively agreedupon obligations, even obligations that might benefit customers by reducing the price of the product, does not ultimately prevent consumers from benefitting from reasonable terms. It merely requires sellers who want to offer such terms to offer them unilaterally.

The drawback of this approach, however, is that it may not always be desirable to stop sellers from agreeing on the terms they offer. Even the antitrust laws do not always condemn such agreements as illegal per se, although the law on this point is somewhat murky. ${ }^{98}$ If courts deciding antitrust cases cannot condemn such agreements without at least some evaluation of the merits of the agreed-upon terms, it might be unwise for courts deciding contract cases to do so. If courts must evaluate the merits of the agreedupon terms in order to decide whether to enforce them, questions about the court's competence at evaluating those terms would once again be dispositive. (1960).

9s See, for example, Henningsen $v$ Bloomfield Motors, Inc., 32 NJ 358, 161 A2d 69, 87

96 Compare National Soc'y of Professional Engineers $v$ United States, 435 US 679 (1978) (condemning an agreement by engineering firms not to bid on a job while any other firm was being considered for the same job), with Vogel $v$ American Soc'y of Appraisers, 744 F2d 598 (7th Cir 1984) (refusing to condemn an agreement by gem appraisers not to charge fees calculated as a percentage of the value they assign to the gem as a result of their appraisal). 
c) Lemons equilibria. Finally, if sellers are competing with each other but buyers are not well-informed, the absence of better terms can result from a "lemons" equilibrium. Because terms that are good for buyers are generally more expensive for sellers, any seller that offers better terms will charge a higher price to make the same level of profits she could make by offering less favorable terms at a lower price. However, if most buyers have good information about prices but only poor information about non-price terms, they may not notice an improvement in non-price terms, while they will definitely notice the higher price. As a result, many buyers may stop purchasing from this seller. If the number of buyers who stop purchasing is sufficiently large, the seller will end up losing money as a result of her decision to offer the more favorable terms at a higher price. In that case, no seller has an incentive to offer the more favorable terms, and the result is an equilibrium in which only bad contract terms (or "lemons") can be obtained..$^{97}$

In markets with this problem, there may well be reasons for doubting the efficiency of the terms selected by sellers. However, courts (or other agencies) might not be any better at selecting efficient terms, or terms that are more desirable according to another appropriate criterion. Thus, in deciding whether this problem should be treated as invalidating Y's consent, the choice should rest entirely on considerations of relative institutional competence. If courts are likely to do worse than the admittedly imperfect market, Y's consent in these cases should still be treated as valid, in

\footnotetext{
${ }^{97}$ For formal economic models of this equilibrium, see George A. Akerlof, The Market for "Lemons": Quality Uncertainty and the Market Mechanism, 84 Q J Econ 488 (1970); Michael Spence, Consumer Misperceptions, Product Failure and Producer Liability, 44 Rev Econ Stud 561 (1977). Akerlof and Spence modeled markets in which consumers had good information about price and bad information about the product's physical characteristics, leading to an equilibrium in which only products with sub-optimal physical characteristics were produced or marketed. However, the analysis can easily be extended to imperfect information about contract terms, by substituting the "quality" of the seller's contract for the physical quality of the seller's product. See, for example, Victor P. Goldberg, Institutional Change and the Quasi-Invisible Hand, $17 \mathrm{~J}$ L \& Econ 461 (1974); Kennedy, 41 Md L Rev at 597-603 (cited in note 42); Comment, Unconscionability in Standard Forms, 64 Cal L Rev 1151, 1177-79 (1976).

Interestingly, if buyers' information could be made even worse, so that every buyer who is poorly informed about a seller's non-price terms is also poorly informed about that seller's price, sellers' incentives respecting non-price terms would then be less seriously distorted. In many cases, the incentive to distort non-price terms might be eliminated entirely (although it might be replaced by an incentive to charge supra-competitive prices). For an analysis of equilibria in which buyers are equally ill-informed about both price and non-price terms, see Alan Schwartz and Louis L. Wilde, Imperfect Information in Markets for Contract Terms: The Examples of Warranties and Security Interests, 69 Va L Rev 1387 (1983).
} 
spite of his inability to obtain better terms from another seller. If courts are likely to do a better job than the market, Y's consent should not be treated as valid-although Y's consent might still be treated as valid in other markets where no better terms can be obtained, such as markets that are perfectly competitive. In short, the choice should rest entirely on the reasons for the market's performance and the prospect of better performance from the courts.

\section{Take-it-or-leave-it negotiating postures.}

Finally, courts and commentators sometimes object to a seller's refusal to negotiate over contract terms in a "take-it-orleave-it" negotiating posture. ${ }^{98}$ Such a posture limits Y's alternatives by forcing him to choose between (a) accepting that seller's terms, or (b) not doing business with that seller. This limitation may not be severe, for nothing in this description precludes there being equally good terms available from some other seller up the street. Thus, most objections to a seller's take-it-or-leave-it posture are probably objections to the adoption of such a posture when no better terms are available, or when one of the other problems discussed in this section is present. ${ }^{99}$ Absent one of these other factors, it is difficult to regard a take-it-or-leave-it posture as sufficient to invalidate Y's consent under any philosophical theory of consent.

The analysis is equally easy under the pragmatic approach advocated here, if we assume that a seller's take-it-or-leave-it posture should (at most) trigger a liability rule. If we wanted to encourage

98 See, for example, Friedrich Kessler, Contracts of Adhesion-Some Thoughts About Freedom of Contract, 43 Colum L Rev 629, 632 (1943) ("[s]tandardized contracts are frequently contracts of adhesion; they are à prendre ou à laisser").

29 Thus, the term "contract of adhesion" is sometimes used to refer to any contract whose drafter adopts a take-it-or-leave-it posture, but is sometimes limited to contracts where the drafter adopts a take-it-or-leave-it posture and the drafter has a monopoly, or where there are no better terms available from other sellers; or to contracts where the drafter adopts a take-it-or-leave-it posture and the contract is a long one full of fine print that many buyers would be unlikely to understand. For a discussion of these and other defining factors, see Rakoff, 96 Harv L Rev at 1176-80 (cited in note 62).

Because of these ambiguities surrounding the term "contract of adhesion," I do not use it here. For similar reasons, I also make no use of the umbrella concept of "unequal bargaining power." While that phrase has never been successfully defined, it does not appear to mean anything other than some combination of the factors already identified and discussed-economic necessity, an inability to obtain better terms elsewhere in the market, or perhaps monopoly or collusion on the part of sellers. For a further discussion of the concept of unequal bargaining power, see Kennedy, $41 \mathrm{Md} \mathrm{L} \mathrm{Rev} \mathrm{at} \mathrm{614-24} \mathrm{(cited} \mathrm{in} \mathrm{note} \mathrm{42);} \mathrm{Alan}$ Schwartz, Seller Unequal Bargaining Power and the Judicial Process, 49 Ind L J 367 (1974); Trebilcock, $26 \mathrm{U}$ Toronto $\mathrm{L} J$ at 363-66 (cited in note 60). 
sellers to haggle over every contract term, a take-it-or-leave-it posture could be met with a property rule, barring any seller who adopts such a posture from enforcing any obligations whatsoever. There is no reason, though, to encourage sellers to haggle over each term-and several reasons not to require such a practice, as every writer to address the question has recognized. ${ }^{100}$ Especially in large-scale enterprises, where the person dealing with customers is an untrained sales clerk, there are obvious drawbacks to authorizing the clerk to redraft the standard contract on the spot. Thus, if $X$ 's take-it-or-leave-it posture is deemed to invalidate Y's consent at all, the most appropriate response is surely a liability rule.

Under the approach urged here, if invalidating Y's consent triggers a liability rule then Y's consent should be invalidated only if there is some reason to think courts can do better than $\mathrm{X}$ in selecting reasonable terms. There is no reason, however, to think that a take-it-or-leave-it posture should distort a seller's incentives respecting the terms she offers, as long as none of the other problems discussed in this section are present. Moreover, none of the problems discussed in this section is in any way aggravated by a seller's adoption of a take-it-or-leave-it posture. Accordingly, the presence of a take-it-or-leave-it posture should be dismissed as irrelevant to the enforceability of X's contract.

\section{B. Inadequate Information}

Even if a buyer has acceptable alternatives to the seller's terms, another class of potential problems may arise if the buyer lacks the information needed to properly evaluate the seller's terms or the available alternatives. One instance of inadequate information-the "lemons" equilibrium, in which the buyer's inability to compare seller's terms reduces the seller's incentive to compete by offering better terms-has already been discussed. In that equilibrium, though, even a buyer who was fully aware of every seller's terms could not find a better term anywhere else on the market. By contrast, the problems discussed in this section arise even if better terms are available from other sellers elsewhere in the market, or even if the alternative of refusing to sign the contract is perfectly acceptable. In other words, the information problems discussed in this subsection (and the psychological

${ }^{100}$ Kessler, 43 Colum L Rev at 631-32 (cited in note 98); Karl L. Llewellyn, What Price Contract-An Essay in Perspective, 40 Yale L J 704, 731-34 (1931); Rakoff, 96 Harv L Rev at $1220-25$ (cited in note 62 ). 
problems discussed in the following subsection) apply to cases where $Y$ would be better off choosing his next-best alternative rather than signing X's contract. The problems discussed in the preceding subsection arose when $\mathrm{Y}$ was indeed better off signing $X$ 's contract rather than accepting his next-best alternative, but his next-best alternative was for some reason deemed inadequate to make his choice truly voluntary.

\section{Fraud.}

The easiest cases to analyze are those involving outright fraud, where $\mathrm{X}$ knowingly misrepresents the object sold, the terms of the contract, or any other fact relevant to Y's decision. The elimination of fraud, like the elimination of gun-to-the-head duress, is easily within X's power. As a consequence, in any case where Y's consent is deemed invalid because of fraud, the courts can protect $Y$ with a property rule.

In some cases, it might be argued that the law should permit fraud in order to protect sellers' incentives to gather and disseminate valuable information. That is, if sellers are not allowed to lie in response to direct questions from buyers, they might not be able to keep their valuable information concealed, which might reduce their incentive to gather that information in the first place. ${ }^{101}$ If this argument is accepted, there is no reason to treat such fraud as invalidating Y's consent in a way that triggers a property rule. The only purpose of a property rule is to discourage the behavior that triggers its application, and if the "justifiable fraud" argument is accepted then this sort of fraud should not be discouraged.

Even if the justifiable fraud argument is accepted, however, it does not necessarily argue against allowing justifiable fraud to trigger a liability rule. That is, even justifiable fraud can invalidate Y's consent, as long as $\mathrm{Y}$ is protected by a liability rule. Certainly, courts applying a liability rule would have to be careful to avoid restricting too severely the obligations that $\mathrm{X}$ is allowed to enforce,

101 See Barnett, 15 Harv J L \& Pub Pol at 794-801 (cited in note 11); compare Kronman, 89 Yale L J at 489-91 (cited in note 74). This argument has been discussed most extensively in connection with the laws governing securities fraud. See Jonathan $R$. Macey and Geoffrey P. Miller, Good Finance, Bad Economics: An Analysis of Fraud-on-the-Market Theory, 42 Stan L Rev 1059 (1990); Jonathan R. Macey and Geoffrey P. Miller, The Fraud-on-the-Market Theory Revisited, 77 Va L Rev 1001 (1991); Ian Ayres, Back to Basics: Regulating How Corporations Speak to the Market, 77 Va L Rev 945 (1991); Paul G. Mahoney, Precaution Costs and the Law of Fraud in Impersonal Markets, $78 \mathrm{Va} \mathrm{L}$ Rev 623 (1992); Marcel Kahan, Games, Lies, and Securities Fraud, 67 NYU L Rev (forthcoming 1993). 
to avoid penalizing $X$ to the point where she is deterred from gathering the information in the first place. In other words, the substantive criteria by which courts evaluate the reasonableness of X's obligation would have to be constrained by the policy of not unduly discouraging the acquisition of valuable information. However, there is no reason why courts could not allow $\mathrm{X}$ to enforce sufficiently favorable obligations to allow her a reasonable return on her information-gathering efforts, while preventing her from overreaching and obtaining an unnecessarily large return. ${ }^{102}$ The only argument against this form of judicial regulation is a fear that courts would not be very good at determining a reasonable rate of return, and might therefore unduly discourage (or unduly encourage) the acquisition of information. In short, once a liability rule is accepted as the best alternative to automatic enforcement of $\mathrm{X}$ 's contract, questions of institutional competence once again become decisive.

\section{Misleading acts or omissions.}

A more plausible argument for not discouraging certain kinds of deception applies to statements which, though misleading in some respects, may also communicate truthful and useful information. For example, during the 1950s and 1960s American advertising law made it difficult, and at times impossible, for any cigarette company to advertise a low level of tar or nicotine. The theory behind the restriction was that consumers might form an exaggerated opinion about the relative safety of brands that made prominent claims about low tar and nicotine levels. The effect, however, was to halt what had been a steady trend toward lower tar and nicotine levels in cigarettes-a trend that did not resume until years later, when the law was changed to allow cigarette companies to advertise improved tar and nicotine levels more freely. In other words, the law's attempt to discourage sellers from making statements that may have misled some buyers made it harder for all buyers to find out about improvements in product safety. ${ }^{103}$

\footnotetext{
102 For analyses of the effect of X's returns on her incentives to gather information-including the possibility that too large a return might induce excessive informationgathering activities-see Cooter and Ulen, Law and Economics at 258-61 (cited in note 39); Steven Shavell, Acquisition and Disclosure of Information Prior to Economic Exchange, Harvard Law School Program in Law and Economics Discussion Paper No. 91 (April 1991).

${ }^{103}$ For more detailed discussions of this history-including evidence that the larger cigarette companies supported the legal ban, to insulate them from the competition of smaller companies who first produced many of the low-tar cigarettes-see John E. Calfee, Cigarette Advertising, Health Information and Regulation Before 1970, U.S. Federal Trade Commis-
} 
Whenever the misleading effects of statements cannot be eliminated costlessly, a trade-off is required to determine what precautions sellers ought to take, and at what cost to other consumers, in order to reduce the risk of misleading some buyers. I have argued elsewhere that this trade-off is similar to one often faced in products liability law, where the issue is whether some product design change by a seller would have reduced the risk of physical injury without unduly detracting from the product's utility. ${ }^{104} \mathrm{~A}$ similar cost-benefit analysis can be applied to misleading advertising: Would any change in the wording of the advertisement produce benefits (by reducing the likelihood that consumers would be misled) in excess of any costs the change would produce (by misleading consumers in other respects, or by reducing the amount of truthful information available to them). Most cases of outright fraud present an easy case under this standard, as their elimination would reduce the risk of misleading consumers without causing consumers to lose any truthful or useful information. In other cases, however-perhaps including the low-tar cigarette claims-the balance would tip in favor of not requiring sellers to modify or eliminate their claims.

The direction in which this balance tips is crucial to the analysis of misleading statements in contract cases. If the court determines that the misleading statements should have been changed, such statements can trigger a property rule to encourage $X$ (and others like her) not to make such statements in the future. On the other hand, if the court is unwilling to decide whether the statements should have been changed, the statements should be treated as (at most) triggering a liability rule. Moreover, the choice between this second option and the third alternative-treating such statements as irrelevant to the enforceability of X's contract-should depend on considerations of institutional competence.

sion Bureau of Economics Working Paper No. 134, (1985); Robert McAuliffe, The FTC and the Effectiveness of Cigarette Advertising Regulations, $7 \mathrm{~J}$ Pub Pol \& Marketing 49 (1988). A. somewhat similar effect was recently observed following the lifting of a legal ban on the use of health information to promote breakfast cereals. Pauline M. Ippolito and Alan D. Mathios, Information, Advertising and Health Choices: A Study of the Cereal Market, 21 RAND J Econ 459 (1990).

${ }_{104}$ Richard Craswell, Interpreting Deceptive Advertising, 65 BU L Rev 657 (1985); Richard Craswell, Regulating Deceptive Advertising: The Role of Cost-Benefit Analysis, 64 S Cal L Rev 549 (1991). 
These three alternatives can be illustrated by considering the advertising involved in Collins $v$ Uniroyal, Inc. ${ }^{100}$ One of Uniroyal's customers was killed when his tire blew out, and his estate sued for breach of warranty. However, Uniroyal's sales contract had disclaimed any liability for consequential damages during the warranty period. The court refused to enforce this limitation, relying in part on Uniroyal's advertising claims concerning the safety of its tires. Uniroyal's ads had claimed: "If it only saves your life once, it's a bargain. . . . You're getting a brute of a carcass that's so strong, you can practically forget about blowouts." 108 This language could have misled some consumers by causing them to form an exaggerated opinion of the extent of Uniroyal's safety advantage.

Interestingly, nothing in the court's opinion rules out the possibility that Uniroyal's tires may have had a significant safety advantage over most other brands. If Uniroyal's tires were in fact safer than most other brands, it is hardly obvious that we want to discourage Uniroyal from calling that fact to consumers' attention. Perhaps Uniroyal could have accurately described its safety advantage without misleading as many consumers, by adding some qualifying language to its ads ("If it only saves your life once, it's a bargain-but you should realize that even Uniroyal tires blow out occasionally, and if the tire does blow out you shouldn't expect Uniroyal to pay for any consequential damages you may suffer.") However, such a disclaimer might not have prevented very many consumers from being misled, especially if many wouldn't have understood the legal significance of the term "consequential damages." Moreover, inserting such a disclaimer in a thirty-second television spot might also distract consumers from the (by assumption) truthful safety claims being made by Uniroyal, thus reducing the effective communication of truthful material.

If the court had decided that Uniroyal should have advertised differently-either by withdrawing the claim entirely, or by adding more qualifying language - the court could then have treated Uniroyal's advertising as sufficient to trigger a property rule. That is, the court could have refused to allow Uniroyal to enforce its limit on consequential damages even if a limit on consequential damages would otherwise be reasonable: even if full liability for consequen-

105126 NJ Super 401, 315 A2d 30, aff'd, 64 NJ 260, 315 A2d 16 (1974). This case also involved a contract that was written in a potentially confusing manner; that aspect of the case will be discussed in the following subsection.

106 Collins, 315 A2d at 34-35. 
tial damages would raise the price of tires by more than consumers were willing to pay. Such a holding would not prevent Uniroyal from enforcing a limit on consequential damages; it would simply prevent Uniroyal from enforcing such a limit without changing its advertising. Thus, this holding also would not call into question the court's ability to evaluate the substantive merits of limits on consequential damages.

To be sure, a decision enforcing a property rule would in this case implicate a different sort of institutional competence. Such a decision would require the court to weigh the informational costs and benefits of certain advertisements, in order to make sure that a property rule is triggered only when the seller should in fact have changed the advertising in question. As the informational costs and benefits of advertising are often difficult to measure, ${ }^{107}$ a high degree of competence may be required to make that determination. Notice, though, that the competence called for here is competence in designing an ideal agreement process, not competence in evaluating the. substance of the resulting obligations. Thus, a court should enforce a property rule if it is more confident in its ability to decide when the seller's advertising should have been changed than in its ability to evaluate the substance of the seller's contract terms.

If the court is not willing to decide that Uniroyal's advertising should have been changed, protecting the buyer with a property rule can no longer be justified. In that event, the court must choose between treating Uniroyal's advertising as (a) triggering a liability rule, or (b) not invalidating the buyer's consent at all. If the court treats Uniroyal's advertising as triggering a liability rule, the court will then have to decide whether Uniroyal's exclusion of consequential damages was reasonable, or whether some court-determined measure of damages should be enforced instead. Obviously, this decision would require consideration of the effect of full liability on the price of tires, as well as a selection of substantive criteria by which that effect could be evaluated. Thus, if the court does not believe that Uniroyal's advertising should have been changed, the choice between applying a liability rule or enforcing Uniroyal's limit automatically should turn on whether we think damage measures selected by the courts are likely to be better than the ones selected by Uniroyal. In other words, the decision should turn on the adequacy of the market incentives facing Uniroyal, and on the

${ }^{107}$ See Craswell, 65 BU L Rev 657 (cited in note 104); Craswell, 64 S Cal L Rev 549 (cited in note 104). 
court's likely competence in evaluating the substance of the seller's terms.

Of course, many arguments can be made on both sides of this institutional competence issue. On one hand, the fact that the court's opinion never even discussed the possible benefits of higher or lower damage measures might make us less than confident about any damage measure selected by the court. On the other hand, if buyers pay little attention to warranties and a good deal of attention to prices, a "market for lemons" might develop that should make us less than confident about the damage measure selected by Uniroyal. ${ }^{108}$ This reason for questioning the warranty selected by Uniroyal has little to do with the language of its advertisement, however, and more to do with the factors affecting the performance of the market in general. In short, if we are unwilling to decide that Uniroyal's advertising should have been changed, the enforceability of its contract should depend primarily on an analysis of market incentives and judicial or administrative expertise, and hardly at all on whether the particular buyer before the court was or was not deceived.

3. Confusing or unreadable contracts.

A similar analysis applies if X's contract is written in a way that misleads $\mathrm{Y}$ into thinking the terms are more generous than they really are. This is the familiar example of a contract that promises a full warranty on its first page or in large print, while taking back most of the warranty in fine-print provisions elsewhere in the contract. ${ }^{109}$ Such a practice has often been analogized to fraud, even by writers who take an economic approach to unconscionability. ${ }^{110}$ However, the proper handling of this problem-like that of misleading advertising, or even some instances of outright fraud-depends on whether the misleading impression is one that we think the seller ought to have prevented.

In some cases, it may be desirable for $\mathrm{X}$ to rewrite her contract to make it less misleading. In these cases, the court should adopt a property rule and prevent $\mathrm{X}$ from enforcing any clauses

${ }^{108}$ See text accompanying note 97.

${ }^{100}$ This criticism was raised against the contracts involved in Gerhardt $v$ Continental Insurance Companies, $48 \mathrm{NJ} 291,225$ A2d 328 (1966) (discussed in text accompanying notes 16-19); Henningsen v Bloomfield Motors, Inc., 32 NJ 358, 161 A2d 69 (1960); and Collins v Uniroyal, Inc., 64 NJ 260, 315 A2d 16 (1974).

${ }^{110}$ See, for example, Posner, Economic Analysis of Law at 113-14 (cited in note 27); Epstein, $18 \mathrm{~J} \mathrm{~L} \&$ Econ at $302 \mathrm{n} 28$ (cited in note 6); Trebilcock, $26 \mathrm{U}$ Toronto L J at 370-71 (cited in note 60). 
written in an unreasonably confusing manner, without regard to the clauses' substantive reasonableness. Adopting a property rule does not permanently bar $\mathrm{X}$ from enforcing reasonable contract terms; it simply prevents her from doing so in a contract that is unnecessarily confusing or misleading. The purpose of such a rule, of course, is to encourage $\mathrm{X}$ not to use such misleading contracts in the future.

In many cases, though, there is little to be gained from making contracts less confusing or more easily readable. If buyers do not read contracts anyway, reducing the contract's length or improving its clarity will not have any effect."11 If so, this does not mean that $Y$ must be treated as having consented to every term in the contract-but it does mean that X's failure to use a simpler contract should no longer trigger a property rule. Instead, either $Y$ should be treated as having fully consented to every term in the contract, or $\mathrm{Y}$ should not be treated as having fully consented but the courts should protect him with a liability rule. These options both abandon the effort to get $\mathrm{X}$ to use shorter or more readable contracts, but the first option enforces any terms chosen by $\mathrm{X}$ while the second option enforces only those terms approved by the court. Accordingly, the choice between these two options should be based on a comparison between X's market incentives and the court's institutional expertise-just as in any other context where a lack of consent could only be protected by a liability rule.

Indeed, there is some evidence that courts may be drawing roughly this distinction under the "reasonable expectations" doctrine. For example, Kenneth Abraham's survey of cases applying the doctrine to insurance contracts distinguishes between those cases where the insurance company in some way caused the insured to believe the policy to be more generous than it actually was, and those in which the insurance company's conduct played no such role. ${ }^{112}$ Only in the latter set of cases does Abraham find courts to be concerned with their own evaluation of the substance of the challenged terms. ${ }^{113}$ Thus, courts may in fact be applying a property rule to cases where the insurance company should have altered its conduct to avoid misleading its customers, and a liabil-

${ }^{121}$ Slawson, $48 \mathrm{~S}$ Cal L Rev at 16-18 (cited in note 64).

112 Abraham, 67 Va L Rev at 1154 (cited in note 54).

${ }^{123}$ Id at 1166. Notice, though, that identifying the insurance company as having "caused" the insured's exaggerated expectation does not always imply that the insurance company should have done something differently. See id at 1173-74 (recognizing that altering the potentially misleading aspect of the policy or the company's behavior may involve costs that exceed any benefit likely to be realized from the alteration). 
ity rule to those cases where the company should not have altered its conduct.

Finally, a similar analysis applies if we consider the possibility that $\mathrm{X}$, rather than making her contract shorter or easier to read, could have pointed out the clauses to $\mathrm{Y}$ and explained them orally. If it is feasible for $\mathrm{X}$ to point out all such clauses, her failure to do so should trigger a property rule, which would bar her from enforcing any clauses that were not so explained. As discussed in Part I, however, many contracts contain so many clauses that they could not all be pointed out orally prior to every sale. ${ }^{114}$ In that case, a court should at most treat X's failure to point out a clause as triggering a liability rule, which would prevent her from enforcing only those obligations that were both not pointed out and deemed unreasonable by the court.

Admittedly, when the only impediment to proper consent is $X$ 's failure to explain the terms of a fine-print contract, the court's substantive evaluation does not have to be quite as fine-tuned as it does when other impediments are present. In particular, an argument might be made for adopting a test for substantive reasonableness that is slightly overinclusive, even if this brands as "unreasonable" a small number of obligations that ought to be enforceable. As long as the number of obligations singled out in this way is not so large as to make it impracticable for sellers to point them all out to buyers, the only consequence of this overinclusiveness is a slight increase in transaction costs as sellers are forced to point out a relatively small number of terms prior to every sale. In this respect, the impediment to proper consent presented by a fine-print contract is somewhat different from the impediment presented by the unconscious patient or the shipwrecked sailor, where there is no way to overcome the impediment and secure the other party's consent with respect to even a single term. The impediment represented by fine-print contracts can indeed be overcome by sellers, if they are only required to overcome it with respect to a small number of terms.

However, even the possibility of being somewhat overinclusive does not free courts from needing some criteria for evaluating the substance of challenged obligations. If the courts paid no attention at all to the substantive merit of the challenged obligations, the outer limits of overinclusiveness could easily be exceeded, and the number of obligations identified as unreasonable would then be-

II See text accompanying notes 16-20. 
come too large to be practicably explained to every buyer. As with any liability rule, a judicial evaluation of the merits of the proposed obligation is essential for the rule to have its desired effect. Accordingly, the choice between treating a buyer as having fully consented to the unexplained terms, or treating him as not having fully consented and protecting him with a liability rule, should once more depend on considerations of institutional competence.

\section{Inadequate Mental Competence}

In some cases, even if a buyer has all the information needed to choose between the seller's contract and the next best alternative, the buyer may be psychologically incompetent to make that choice. Of course, defining "psychologically competent" is difficult even as a matter of theory; identifying psychological competence in practice is even harder. ${ }^{115}$ Even in this difficult area, however, there are benefits to distinguishing between property rules and liability rules.

\section{Undue influence.}

In some cases the condition that reduces the buyer's competence is temporary, usually the result of some emotional shock. These are the cases involving widows approached the day after their husband's funeral and persuaded to deed away their interest in their husband's estate, ${ }^{116}$ or schoolteachers persuaded to resign after going without sleep for forty hours following their arrest for "homosexual activity."117

In these cases, if $\mathrm{X}$ had no particular need to close the deal at that time, Y's diminished competence could easily have been corrected, simply by waiting until he had a chance to recover from his emotional shock. Accordingly, if $\mathrm{Y}$ should be given any protection at all in these cases, it should probably be the protection of a property rule rather than a liability rule. That is, if $\mathrm{X}$ unnecessarily

${ }^{116}$ For a useful discussion of the standard tests for mental competence in contract law, see Meiklejohn, 39 Case W Res L Rev 307 (cited in note 83). More skeptical views can be found in Green, 53 Yale L J 271 (cited in note 83); Kennedy, $41 \mathrm{Md}$ L Rev at 631-49 (cited in note 42); George J. Alexander and Thomas S. Szasz, M.D., From Contract to Status via Psychiatry, 13 Santa Clara Law 537 (1973). There is, of course, a much larger literature describing and criticizing the tests used to judge mental competence in other legal contexts. See, for example, Stephen J. Morse, Crazy Behavior, Morals, and Science: An Analysis of Mental Health Law, 51 S Cal L Rev 527 (1978); Elyn R. Saks, Competency to Refuse Treatment, 69 NC L Rev 945 (1991).

${ }_{118}$ Moore v Moore, $81 \mathrm{Cal} \mathrm{195,} 22$ P 589 (1889).

117 Odorizzi v Bloomfield School District, 246 Cal App 2d 123, 54 Cal Rptr 533 (1966). 
refuses to wait until Y's competence has returned to normal, $\mathrm{X}$ should be barred from enforcing any obligations against $\mathrm{Y}$, even those whose substance seems perfectly reasonable. The purpose of such a rule would be to encourage $X$ and $Y$ to decide for themselves which obligations are reasonable once Y's competence has returned to normal, rather than allowing $\mathrm{X}$ to shift that decision to a reviewing court.

Interestingly, some courts have made X's ability to wait out Y's temporary incompetence part of the defining elements of undue influence. Traditional definitions of undue influence-for example, persuasion "which overcomes the will without convincing the judgment"118 - are notoriously difficult to apply, especially in a way that distinguishes truly objectionable cases from ordinary sales techniques. Thus, one leading opinion suggests that a finding of undue influence should turn on some combination of the following factors:

(1) discussion of the transaction at an unusual or inappropriate time, (2) consummation of the transaction in an unusual place, (3) insistent demand that the business be finished at once, (4) extreme emphasis on untoward consequences of delay ..... .119

This definition focuses on precisely those aspects of X's conduct that can be and should have been avoided. In other words, these are precisely the aspects of X's conduct that justify applying a property rule rather than a liability rule.

2. Incapacity.

If the buyer's diminished competence is not merely temporary, the choice between a property rule or a liability rule is more complex. If $Y$ is permanently insane, it is hardly practicable to tell any $\mathrm{X}$ who has a substantively reasonable proposal that she should wait until Y's competence returns, when his proper consent can be obtained. The same is true when Y's incapacity stems from his status as a minor. As $\mathrm{X}$ cannot practicably correct either of these sources of diminished competence, it can be argued that $Y$ should be protected at most with a liability rule. Courts often do enforce reasonable obligations against persons who might otherwise be deemed permanently incompetent-either by striking down the

118 Id at 130.

119 Id at 133 (emphasis added). The other factors listed by the Odorizzi court are discussed in note 121 . 
contract but allowing $\mathrm{X}$ to sue for the reasonable value of her services in restitution, or by ruling that $\mathrm{Y}$ was in fact competent when $X$ 's proposal seems substantively reasonable. ${ }^{120}$

Even when Y's incompetence is relatively permanent, however, it may still be appropriate to protect $\mathrm{Y}$ with a property rule if $\mathrm{X}$ could have avoided the problem by dealing with Y's guardian. For example, if $\mathrm{Y}$ is judged legally insane and has a guardian appointed, any $\mathrm{X}$ who believes her proposed contract to be reasonable should be required to approach Y's guardian and obtain his or her agreement to the contract, rather than inducing an incompetent $\mathrm{Y}$ to sign the contract and then asking the court to perform the guardian's function. After all, one rationale for appointing guardians (rather than having the court itself serve as the guardian) is to spare courts the need to make such day-to-day decisions for incompetent parties, by entrusting those decisions to someone who will have a closer knowledge of Y's affairs and a closer sympathy with Y's interests. A similar analysis could apply to buyers who are underage, but who have a parent or other legal guardian that the seller could have contacted.

If $\mathrm{Y}$ does not have an official guardian, the problem is more difficult. Even in these cases, though, it may be preferable to solve the problem by having $\mathrm{Y}$ consult some competent adviser (a friend, clergyman, or lawyer) who could advise him about X's offer, rather than having the court fulfill that role. In other words, X's failure to encourage or allow an incompetent $Y$ to seek independent advice might itself be grounds for protecting $\mathrm{Y}$ with a property rule rather than a liability rule, if we believe that the use of such third-party advisors ought to be encouraged. ${ }^{121}$ In this situation, therefore, a decision about whether to treat X's failure to involve a third-party advisor in the process requires yet another institutional competence assessment-in this case, an assessment of the relative competence of the third-party advisor as compared to the court. The better the quality of the advisors available to $\mathrm{Y}$ (including a courtappointed legal guardian), the stronger the case for treating $X$ 's failure to involve those advisers as triggering a property rule.

120 See text accompanying note 83 .

121 The other factors cited by the Odorizzi court as possible determinants of undue influence were:

(5) the use of multiple persuaders by the dominant side against a single servient party,

(6) absence of third-party advisers to the servient party, (7) statements that there is no time to consult financial advisers or attorneys.

246 Cal App 2d at 133 (emphasis added). 
Finally, in cases where no acceptable guardian is available and Y's incompetence is relatively permanent, protecting $Y$ with a property rule would obviously be undesirable. A property rule applied to such a case would prevent $Y$ from entering into any enforceable contracts whatsoever, making it difficult for $\mathrm{Y}$ to obtain goods or services. To avoid this result, courts must (and do) protect $\mathrm{Y}$ with something closer to a liability rule, under which obligations that seem reasonable to the court may be enforced. In these cases, therefore, courts must address all the issues discussed earlier in Section I.B, concerning the possible "reasonableness" criteria that might be employed. In particular, the court must concern itself with the price that will be charged for any additional protection it might require from $\mathrm{X}$, and with deciding which protections would be worth that higher price. Only if we are confident that the court will be able to make these judgments better than $Y$ should we treat Y's diminished competence as invalidating his apparent consent.

\section{CONCLUSION}

As has often been noted, economists and non-economists tend to approach unconscionability from very different perspectives. ${ }^{\mathbf{1 2 2}}$ Standard economic theory holds that perfectly competitive markets will maximize consumer welfare, so most economists conclude that contracts should be overridden only if there is some "market failure" which prevents this outcome from being realized, and even then only if the government can do a better job than the market. Accordingly, most economists focus their inquiry on the performance of the market as a whole and on the competence of government agencies, rather than on the behavior of individual parties to a single transaction. By contrast, non-economists tend to focus on individual transactions, in order to ask whether the weaker party knowingly and voluntarily consented to the obligation in question. Moreover, most non-economists look to philosophical or legal theories of consent to define the conditions needed to make an individual transaction truly knowing or voluntary. They thus reject the economists' conclusion that the enforceability of a contract should

${ }^{122}$ For example, Comment, $64 \mathrm{Cal} \mathrm{L} \mathrm{Rev} \mathrm{at} \mathrm{1153-57} \mathrm{(cited} \mathrm{in} \mathrm{note} \mathrm{97);} \mathrm{Schwartz} \mathrm{and}$ Wilde, 127 U Pa L Rev at 635-39 (cited in note 65); Katz, 21 RAND J Econ at 520-22 (cited in note 29 ). 
depend not on philosophical theories of consent, but on whether the market as a whole is working efficiently. ${ }^{123}$

Unfortunately, participants on both sides of this debate tend to approach the problem as a simple question of "whether X's contract ought to be enforced," without paying much attention to the legal consequences that might follow non-enforcement. In particular, little attention has been paid to the distinction between refusing to let $\mathrm{X}$ enforce any obligations whatsoever, as opposed to refusing to let her enforce any obligations except those the court considers reasonable - that is, to the distinction between property rules and liability rules. As a consequence, it is not surprising that there has been no discussion of which reasons for invalidating a contract ought to trigger a property rule, and which ought to trigger a liability rule. Nor has much attention been paid to the criteria by which courts might evaluate the substantive reasonableness of an obligation, in cases where a liability rule is appropriate.

In this Article, I have suggested tentative answers to all of these questions. For example, the choice between property rules and liability rules ought to depend on the cost of overcoming the impediment to consent that provides the reason for invalidating $X$ 's contract. If the impediment can easily be overcome, protecting $\mathrm{Y}$ with a property rule will usually be appropriate, but if the impediment cannot be overcome, or can only be overcome at great expense, then if $\mathrm{Y}$ is to be protected at all it will usually be better to adopt a liability rule. Moreover, the choice between either of these options and the third possible outcome-enforcing X's contract automatically, without any judicial scrutiny of its reasonableness-should turn on different considerations depending on whether the best alternative to automatic enforcement is a liability rule or a property rule. If the choice is between enforcing X's contract or applying a liability rule, $Y$ will be bound either by terms that $\mathrm{X}$ selected (if the contract is enforced) or by terms deemed reasonable by the courts (if the contract is invalidated). A comparison of the terms likely to be selected by $\mathrm{X}$ and by the courts-that is, an economic analysis of X's market incentives and the competence of the legal institutions-is therefore crucial to choosing the proper rule for these cases. Moreover, as neither of these outcomes will make Y's consent any more informed or any more voluntary, philosophical theories of autonomy and consent

${ }^{123}$ For example, Slawson, 46 U Pitt L Rev at 42 (cited in note 54), criticizes recent economic analysis for concluding "that courts ought to enforce whatever terms a seller chooses to impose without regard to whether a buyer has agreed to them." 
are largely irrelevant to the choice of outcome. On the other hand, when the choice is between enforcing a contract and applying a property rule, the court will either enforce X's terms (if the contract is upheld) or seek to encourage a better negotiation process (if not), and in neither case will the court have to decide for itself which obligations are substantively reasonable. In this class of cases, concerns about the relative performance of courts and markets are largely irrelevant to the proper outcome, while processbased theories (including most philosophical theories of consent) may have more to contribute.

Others may, of course, disagree with the answers I have suggested. Even for those who agree, there is much work still to be done in analyzing market failures and institutional competence for those cases where a liability rule would be most appropriate, and in developing criteria for evaluating the substantive reasonableness of contested obligations. My main point, however, is that none of these questions can even be framed until unconscionability is seen as more than just a matter of whether $Y$ consented to X's terms, or even of whether X's contract ought to be enforced or not. Instead, the phrase "enforced or not" must be unpacked into at least three possibilities: automatic enforcement, protection of $\mathrm{Y}$ with a property rule, or protection of $\mathrm{Y}$ with a liability rule. Only then can the key issues in unconscionability cases be addressed. 


$$
\text { . }
$$

